\title{
Dissecting Molecular Genetic Mechanisms of 1q21.1 CNV in Neuropsychiatric Disorders
}

\author{
Joy Yoon (1) and Yingwei Mao *(1) \\ Department of Biology, Eberly College of Science, Pennsylvania State University, University Park, PA 16802, USA; \\ jfy5125@psu.edu \\ * Correspondence: yzm1@psu.edu; Tel.: +1-814-867-4739
}

check for updates

Citation: Yoon, J.; Mao, Y. Dissecting Molecular Genetic Mechanisms of 1q21.1 CNV in Neuropsychiatric Disorders. Int. J. Mol. Sci. 2021, 22, 5811. https://doi.org/10.3390/ ijms22115811

Academic Editor: Kunio Yui

Received: 23 April 2021

Accepted: 25 May 2021

Published: 28 May 2021

Publisher's Note: MDPI stays neutral with regard to jurisdictional claims in published maps and institutional affiliations.

Copyright: (C) 2021 by the authors Licensee MDPI, Basel, Switzerland. This article is an open access article distributed under the terms and conditions of the Creative Commons Attribution (CC BY) license (https:// creativecommons.org/licenses/by/ $4.0 /)$.
Abstract: Pathogenic copy number variations (CNVs) contribute to the etiology of neurodevelopmental/neuropsychiatric disorders (NDs). Increased CNV burden has been found to be critically involved in NDs compared with controls in clinical studies. The 1q21.1 CNVs, rare and large chromosomal microduplications and microdeletions, are detected in many patients with NDs. Phenotypes of duplication and deletion appear at the two ends of the spectrum. Microdeletions are predominant in individuals with schizophrenia (SCZ) and microcephaly, whereas microduplications are predominant in individuals with autism spectrum disorder (ASD) and macrocephaly. However, its complexity hinders the discovery of molecular pathways and phenotypic networks. In this review, we summarize the recent genome-wide association studies (GWASs) that have identified candidate genes positively correlated with 1q21.1 CNVs, which are likely to contribute to abnormal phenotypes in carriers. We discuss the clinical data implicated in the 1q21.1 genetic structure that is strongly associated with neurodevelopmental dysfunctions like cognitive impairment and reduced synaptic plasticity. We further present variations reported in the phenotypic severity, genomic penetrance and inheritance.

Keywords: copy number variation; microdeletion; microduplication; schizophrenia; autism spectrum disorder; microcephaly; macrocephaly; neurodegeneration; synaptic plasticity

\section{Introduction}

Rare CNVs, such as chromosomal deletions and duplications, have raised much scientific interest in etiological studies of NDs. It has been suggested that genetics play a major role in NDs, with $\sim 52.4 \%$ and $\sim 80 \%$ of inheritability in ASD and SCZ, respectively. A genetic study has shown that rare and large CNVs are likely to be causative, as they can lead to numerous gene imbalances [1]. Case-control studies have demonstrated that rare CNVs occur at higher frequency in cases than in controls, suggesting that patients bear a high CNV burden [2,3]. Moreover, 17.1\% of those who presented abnormal clinical presentations carried pathogenic CNVs [4]. Approximately $40 \%$ of carriers had de novo mutations, and the majority of the de novo mutations (91\%) were pathogenic [4]. These patterns show up in most ND studies, including ASD, SCZ, intellectual disability (ID) and attention deficit hyperactivity disorder (ADHD) [5-7]. These findings shed light on the contribution of CNVs to the risks of different NDs.

In general, CNVs are pleiotropic and have variable expressivity, in that different patients carrying CNVs at the same chromosomal regions can show the symptoms of different psychiatric disorders; for example, many ASD-associated CNVs are also found in SCZ patients $[3,4,8,9]$. Despite having the same CNV carriers, phenotypes and severity range diversely, and show incomplete penetrance [10]. This suggests that there must be other factors involved, such as other genetic components (the two-hit model) [11] or environmental factors [12]. Hence the complexity of CNVs has been underscored in the etiology of ND.

A recent GWAS has identified risk loci prevalent in NDs, which are rare CNVs seen in cases but not in controls [2]. At least eight distinct CNVs,1q21.1, 2p16.3, 3q29, 7q11.23, 
15q13.2, 16p11.2, 22q11.2 and NRXN1, have been consistently reported as risk factors for many NDs [6-8,13-15]. Deletions are less frequent but more pathogenic than duplications. Therefore, an increased odds ratio (OR) was found for deletions (i.e., ORs of 1q21.1 = 11.82 (del) and $=6$ (dup)) [15]. The abnormal clinical presentations are postulated to be a result of carrying those pathogenic CNVs. Many genetic studies have attempted to identify the relationships between genetic rearrangements in the regions and clinical phenotypes. As little is known about their effect size, penetrance and genetic predisposition towards a certain phenotype, it is too early to use those rare CNVs for diagnoses of any NDs.

Among the aforementioned associated CNVs, this paper aimed to focus on the 1q21.1 $\mathrm{CNV}$ that is found with high incidence in ASD, SCZ, ADHD, ID and epilepsy [16]. Due to its structural complexity and inconsistent clinical phenotypes, this genetic locus has been understudied. A significant and popular finding in 1q21.1 is its mirror effect on neurodevelopment: microdeletions are widely found in the cases of SCZ, and microduplications are widely found in the cases of ASD [17]. This review will discuss the genetic structure of the chromosome 1q21.1 at the molecular and cellular levels and summarize clinical phenotypes associated with the genetic rearrangement.

\section{Chromosomal Mapping and Genetic Pathway of 1q21.1}

\subsection{Chromosomal Structure}

The $1 \mathrm{q} 21.1 \mathrm{CNV}$ is found within a 144 to $148 \mathrm{Mb}$ region [18] (Figure 1a). In contrast to small CNVs, which are less detrimental, larger CNVs ( $>500 \mathrm{~kb}$ in size) can alter the expression levels of multiple genes [19]. It is a complex locus to study in that it not only spans $20-40$ putative genes, but the region is also susceptible to genomic rearrangements due to the numbers of low copy repeats (LCRs). The more LCRs in the region, the more prone it is to frequent non-allelic homologous recombination (NAHR) during meiosis [20]. Clustered with LCRs, breakpoints (BPs) divide the locus into four possible segmental blocks and complicate the mapping and prediction of phenotypic expressivity [18]. Many of the LCRs and BPs are located adjacent to the crossing over points, making it difficult to estimate the phenotypes or genomic sequences in any given persons [21]. Through this mechanism, the CNVs, emerging in chromosomal duplications or deletions, can alter some of the dosage-sensitive genes and create a broad range of phenotypic variability [22]. Array comparative genomic hybridization and fluorescent in-situ hybridization analyses mapped out the overall structure of the 1q21.1 in great detail. The 1q21.1 region is associated with mental retardation, autism [23], schizophrenia [24] and microcephaly [21]. Duplication of $1 \mathrm{q} 21.1$ is strongly associated with autism [21].

Duplications and deletions are classified into two classes: Class I and Class II. Class I duplication/deletion involves only the distal 1q21.1 region between BP3 and BP4 (1.35 Mb in size), whereas Class II duplication/deletion extends from the distal 1q21.1 to the proximal 1q21.1 commonly detected between BP2 and BP4 ( 3 Mb) [21] (Figure 1c). Combined data show enrichment in Class I deletions and duplications with a parental origin, but the components of genes and BPs can be varied after generations [25]. Both analyses discovered two distinct regions: proximal and distal 1q21.1, where a genomic gain or loss occurs (Figure 1b) [21,26]. Microdeletions at proximal 1q21.1 are mainly associated with thrombocytopenia-absent radius (TAR) syndrome and this region is often referred to as the TAR region. In particular, a core exon junction complex gene, $R B M 8 A$, is located in the TAR region and compound mutations in the RBM8A gene cause the TAR syndrome [27] that is comorbid with ID [28]. Other brain dysfunctions, including psychosis, agenesis of the corpus callosum and hypoplasia of the cerebellar vermis, are present in TAR patients [28-30]. Consistent with human patient studies, knockdown and knockout of $\mathrm{Rbm} 8 \mathrm{a}$ in a mouse model revealed the critical role of RBM8A in neural progenitor cell (NPC) proliferation, neuronal migration and interneuron development, and loss of function in RBM $8 A$ in NPCs causes microcephaly [31-33]. Moreover, $R B M 8 A$ plays a key role in adult neurogenesis and in regulating anxiety-related behavior [34], further supporting the important role of $R B M 8 \mathrm{~A}$ in psychiatric diseases. 
(a)

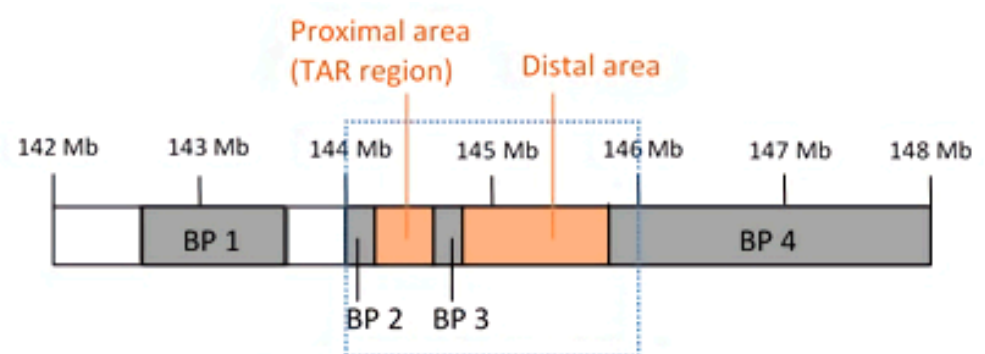

(b)

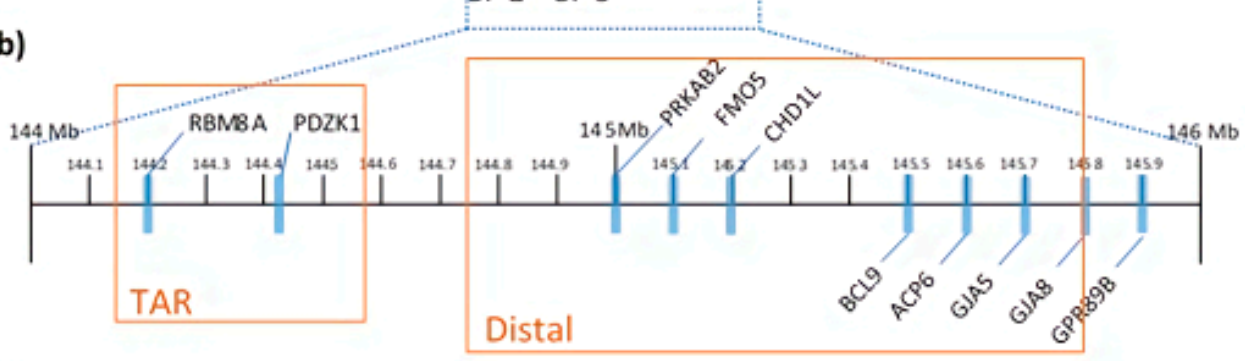

(c)

\section{Class I duplication/deletion (1.35 Mb)}

\section{Class II duplication/deletion ( $\sim 3 \mathrm{Mb}$ )}

Figure 1. (a) Chromosomal structure of 1q21.1, mapped with four BPs (gray) and two distinct regions (red). (b) An enlargement of the region between $144 \mathrm{Mb}$ and $146 \mathrm{Mb}$. Known genes commonly found in microduplication and microdeletion carriers are marked with blue bars. The reference locations on the chromosome are based on the March 2006 human reference sequence (NCBI build 36.1). The two distinct regions-TAR and Distal-are indicated by red blocks. (c) The two classes of duplications and deletions are shown with green bars. The size of the bars represents the minimally affected region in each class.

\subsection{Genetic Architecture}

The recent advanced genomic assay has deciphered the genes encoded in the region and the position on the locus. The core genes commonly affected in the 1q21.1 CNV carriers are PRKAB2, FMO5, CHD1L, BCL9, ACP6, GJA5, GJA8, GPR89B and PDZK1 $[25,35,36]$ (Figure 2; Table 1). However, the genetic study of the risk genes is far from clear as to the phenotypic consequences. Reported clinical phenotypes of the 1q21.1 duplication and deletion are not consistent, and no single gene has been confirmed to cause a pathologic effect in human studies [36].

This complex expressivity can be explained by a cis-epistasis genetic model. In contrast to a single gene CNV model, the gene expression is regulated by one or more $\mathrm{CNV}$ drivers and multiple modifiers [37]. Gain or loss of a single gene contributes only a small effect to trigger explicit clinical phenotypes [38]. This was confirmed in a number of genotype-phenotype association studies. A correlation analysis between gene expression and the copy number of 1q21.1 indicated that the candidate genes drew a positively correlated trend, in which a duplication CNV model was likely to have increased gene expression and vice versa [25], but the clinic severity may not have been correlated with the level of gene expression [39]. Harvard et al. conducted a family-based study of 1q21.1 microdeletion and microduplication and showed that individuals with the same CNV exhibited different levels of severity despite the identical gene components and almost identical BPs. Entangled chromatids are increased in lymphoblast cells derived from patients carrying both duplication and deletion of 1q21. To narrow down the causal gene, they identified two candidate genes, CHD1L and PRKAB2. Knockdown of CHD1L led to increased micronuclei in response to a topoisomerase II inhibitor, ICRF-193. However, both deletion and duplication carriers show the same cellular phenotype, suggesting that the gene dosage difference may not correlate with severity of symptoms. These findings once again emphasize the characteristic of the variable expressivity and the cis-epistasis model 
of the 1q21.1 CNVs [40,41]. Nevertheless, understanding of a linkage between genetic imbalance and apparent phenotypes is still incomplete.

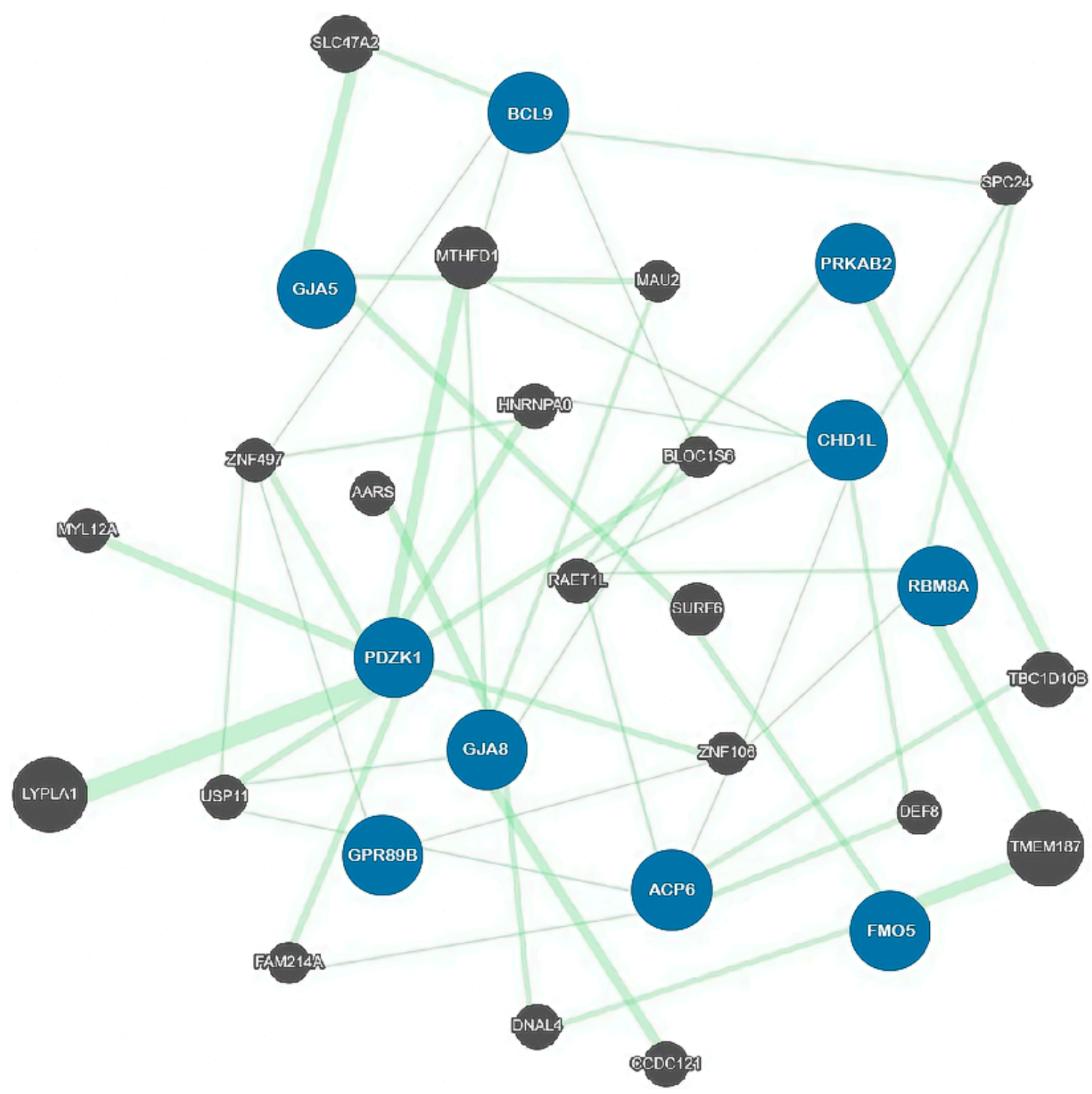

Figure 2. A genetic map of the associated genes observed in 1q21.1 microduplications and microdeletions. Blue circles are the 10 affected genes; black circles are the 20 related genes. None of the 10 core risk genes interacts directly with another. A total of 49 genetic linkages are drawn with different widths of green lines and were generated by the GeneMANIA program [42]. Gene expression of the candidate genes is positively correlated with the copy number of 1q21.1 but not with phenotypic severity. Even within the same genetic components, clinical presentations are shown to a different extent in cases, which denies the one gene-one phenotype module. The blue circles are the major genes discussed in the paper. Eight top-ranked genes in the correlation study are not directly linked to each other but are indirectly connected via subtype genes. 
Table 1. Genetic function and known phenotypes of dosage-sensitive genes associated with 1q21.1.

\begin{tabular}{cccc}
\hline & \multicolumn{1}{c}{ Function $^{\mathbf{1}}$} & Molecular/Cellular Phenotypes & References \\
\hline CHD1 & $\begin{array}{c}\text { Chromatin remodeling and DNA } \\
\text { damage response }\end{array}$ & $\begin{array}{c}\text { Impaired decatenation checkpoint } \\
\text { activation }\end{array}$ & {$[25]$} \\
\hline PRKAB2 & $\begin{array}{c}\text { AMPK regulatory subunit; } \\
\text { maintaining energy homeostasis }\end{array}$ & $\begin{array}{c}\text { Neurodegeneration; learning and memory } \\
\text { impairment }\end{array}$ & {$[42]$} \\
\hline GJA8 & Gap junction protein; Connexin50 & $\begin{array}{c}\text { Cataracts; cardiac myopathy; increased } \\
\text { risk of SCZ }\end{array}$ & {$[43,44]$} \\
\hline GJA5 & Gap junction protein; Connexin40 & Cataracts; cardiac abnormalities & {$[18,45,46]$} \\
\hline PDZK1 & $\begin{array}{c}\text { Ion transporter protein; regulates } \\
\text { second messenger cascades }\end{array}$ & Increased risk of ASD and psychosis & {$[36]$} \\
\hline GPR89B & Voltage dependent anion channel & Unknown & {$[47]$} \\
\hline BCL9 & Wnt signaling pathway & Increased risk of SCZ & {$[48,49]$} \\
\hline FMO5 & Modulator of metabolic aging & Unknown & \\
\hline ACP6 & Histidine acid phosphatase protein & \multicolumn{1}{c}{ The Genecards Human Gene Database. }
\end{tabular}

\subsection{Pathogenesis of Proximal 1q21.1}

These clinical manifestations are associated with the genomic segmental regions on 1q21.1. The frequency of the chromosomal abnormalities was highly skewed to distal regions compared with proximal regions. Minimal deletions in BP2-BP3, known as the TAR syndrome region, however, raised a question of whether this region is benign or pathogenic. The overall chromosomal abnormalities in the proximal region were less frequent than in the distal region. However, the relative enrichment of proximal 1q21.1 in microduplication, especially with a low ratio of de novo inheritance compared with the microdeletions, suggests that the proximal BP2-BP3 region is responsible for clinical microduplication aberrations and is mild enough to maintain fecundity $[50,51]$. Bearing in mind that developmental delay (DD) is a common history in microdeletions and microduplications, the genes within the proximal BP2-BP3 region account for cerebral development in addition to TAR syndrome [51]. On the other hand, even though the head size was a notable phenotype by dosage, head sizes between the proximal microdeletions and microduplications were not found to be discrete, suggesting that the genes in the proximal region are not sufficient or not responsible for microcephaly/macrocephaly [51]. These findings confirmed the pathogenicity of the proximal 1q21.1 region; this should be re-evaluated on a large scale to be supportive.

\section{Dosage Effect on Molecular and Clinical Phenotypes}

\subsection{Clinical Manifestation of $1 q 21.1$}

Carriers of the 1q21.1 duplication or deletion share some similar spectra of symptoms. Clinic presentations appearing to be mirrored could be due to the converging downstream pathways of chromosomal deletion and duplication [37]. Two major disorders in the spectrum are ASD and SCZ, which are associated with duplication and deletion of the 1q21.1 region, respectively. The complex symptoms of SCZ typically start in late adolescence or early adulthood and lead to a lifetime of treatment for SCZ patients. According to Diagnostic and Statistical Manual of Mental Disorders (DSM-5), they are generally divided into three categories: positive, negative and cognitive. The positive symptoms include hallucinations, delusions and disorganized thoughts. The negative symptoms include a reduction in, or lack of, motivation, affective response, verbal speech, attention and enjoyment. SCZ patients also suffer from cognitive impairment, which includes deficits in attention, language, memory and executive function. Cognitive impairment has been seen in people with SCZ before the onset of positive symptoms, and there is a moderate and 
appreciable decline throughout their lifetime [52]. Additionally, SCZ patients suffer from other comorbidities, including substance abuse [53-58]. The clinical presentations of ASDs show that the impaired social-communication functions and restricted, repetitive patterns of behavior can be detected in children with ASD at the age of 2-3 years. The clinical presentations are highly variable. Patients with ASD often have an increased risk of other neuropsychiatric symptoms, including anxiety [59], memory deficit [60], hyperactivity, aggression and epilepsy. ASD patients are often comorbid with ID.

The 1q21.1 CNVs have been widely reported in ND studies. Consistent with pleiotropic traits, this CNV is associated with other psychiatric disorders [22,61]. Published data on 1q21.1 CNVs carriers have shown psychiatric symptoms, including ADHD; ID; internalizing disorders such as depression, anxiety and bipolar disorder; and microcephaly/macrocephaly $[18,25,35,62]$. Non-neurologic syndromes such as congenital anomalies, cataracts and short stature are prevalent in probands with 1q21.1 CNV [50]. These features were not significantly distinct between deletions and duplications, but were distinct from controls [35]. Many comparison studies have attempted to validate these frequent diagnoses with the 1q21.1 CNVs.

Case series studies have evidenced a phenotypic association with deletions and duplications. Microduplications show various and indefinite phenotypes, while deletions show a relatively consistent pattern [3]. Among neuropsychiatric disorders, cumulative literature ascertained that $\mathrm{SCZ}$, microcephaly or relative microcephaly diagnoses were substantially higher in probands carrying microdeletions, and ASD, ADHD and macrocephaly or relative macrocephaly diagnoses were substantially higher in cases with microduplications $[5,18,25,35,36,40,51,63,64]$. Other recognizable syndromes also showed a distinguishing dosage effect, even though it was not constant, such as facial dysmorphism, heart and renal anomalies and behavioral problems (Figure 3, Table 2) $[35,36,45,65]$.

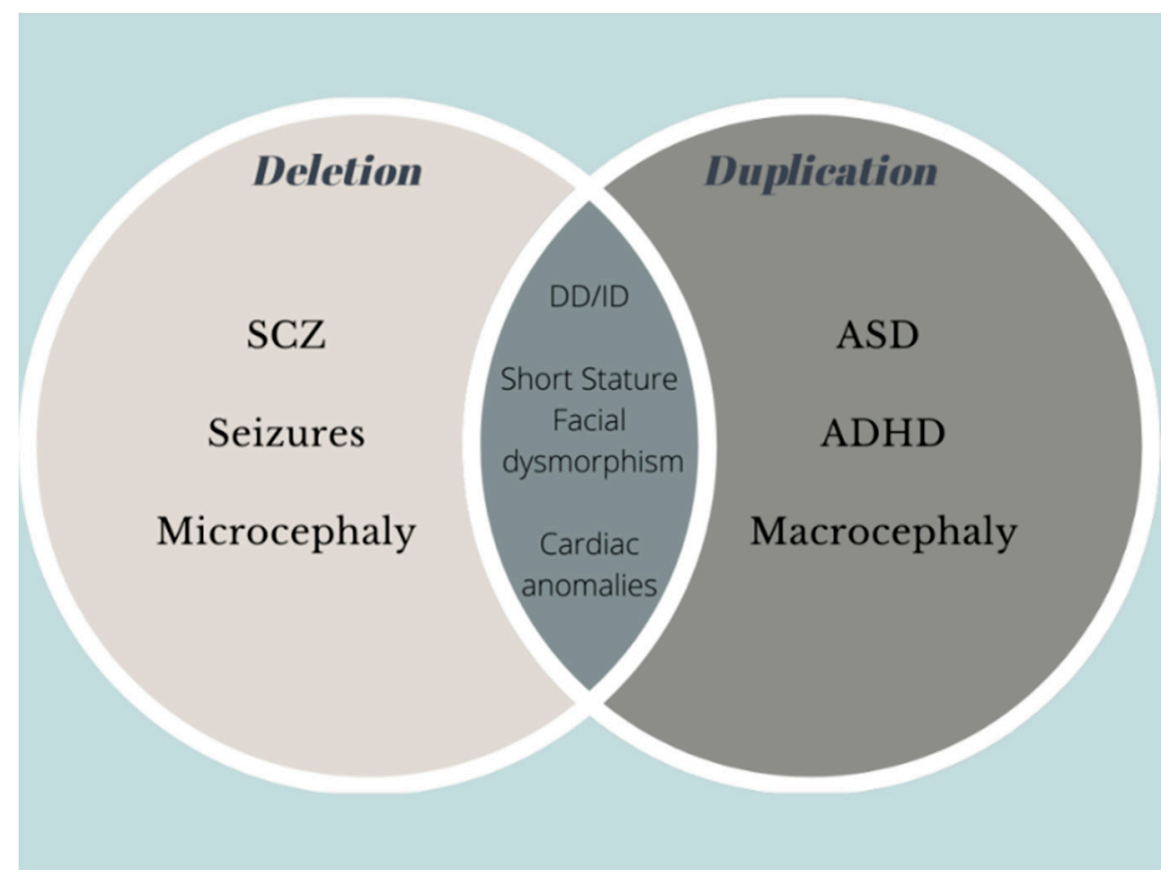

Figure 3. Venn diagram of phenotype association with 1q21.1 microdeletions and microduplication. 
Table 2. Case reports of neurodevelopmental diseases with 1q21.1 duplications and deletions.

\begin{tabular}{|c|c|c|c|c|c|c|c|c|c|c|c|c|c|}
\hline \multirow{2}{*}{ References } & \multicolumn{6}{|c|}{ Duplication (2nd CNV Cases) } & \multicolumn{6}{|c|}{ Deletion (2nd CNV Cases) } & \multirow{2}{*}{$\begin{array}{l}\text { Total } \\
\text { Cases }\end{array}$} \\
\hline & ASD & SCZ & ID & ADHD & TAR & Other DD & ASD & $\mathrm{SCZ}$ & ID & ADHD & TAR & Other DD & \\
\hline [35] & 7 & & 5 & 5 & & 4 & 2 & & 2 & 1 & & 3 & 29 \\
\hline [21] & 3 & & & 1 & & 13 & 1 & & & 2 & & 16 & 36 \\
\hline [18] & 4 & & & & & $5(1)$ & 2 & & & 2 & & $16(2)$ & 32 \\
\hline [51] & 3 & & & 5 & & 11 & 4 & & 1 & 3 & 4 & $25(5)$ & 61 \\
\hline [50] & 3 & & 3 & 3 & & 2 & & & 5 & 1 & 1 & 4 & 22 \\
\hline [66] & $3(1)$ & & & & & & 1 & & & & & & 5 \\
\hline [13] & & 8 & & & & & & $10(2)$ & & & & & 20 \\
\hline [8] & & 1 & & & & & & 4 & & & & & 5 \\
\hline [9] & & & & & & & & 10 & & & & & 10 \\
\hline
\end{tabular}

All reported cases are single CNV carriers except for the 2nd CNV carriers, which are stated within parentheses. All cases include de novo and inherited CNVs. A blank cell indicates that the data are not available.

\subsection{Cognitive Impairment}

The 1q21.1 CNVs show a strong association with developmental disabilities, including ASD [67], SCZ [8] and ADHD [64]. A large dataset indicates that individuals with developmental disabilities commonly accompany a history of cognitive deficits (Table 2). Most SCZ and ASD patients show cognitive impairment [6,7]. Larger CNVs, not limited to 1q21.1, led to a reduction of median IQ in a group of carriers [5], and SCZ-associated CNVs commonly confer a high risk of other mental disorders including ASD and ADHD, depending on the gene dosage $[5,65]$. Thus, the cognitive ability in patients is influenced by the risk CNVs (e.g., 1q21.1) during neurodevelopment, and cognitive deficit may contribute to pathophysiological outcomes in ASD, SCZ or ADHD.

\subsection{Head Size and Neural Abnormalities}

Head size variation is another substantial phenotype mediated by genetic imbalance. It has been clearly replicated in many studies after the first clinical report of 1q21.1 examined the mean head circumference among carriers and found statistical significance (mean $Z$ score for microdeletions: -2.55 ; microdeletion: +1.15 ; unpaired $t$-test, $p<0.0001$ ) [21]. Recent studies focused on brain morphology with respect to gene dosage, since aberrant head shape during neurodevelopment may have disrupted the subsequent neuronal function, resulting in decreased axonal density. It has been hypothesized that head size abnormalities are driven by one of the candidate genes for neurological presentations such as neuronal differentiation and migration seen in 1q21.1 [36]. The copy number of the DUF1220 domain, encoded in the neuroblastoma breakpoint family (NBPF) gene family in 1q21.1, shows a strong correlation with brain size and neocortex volume [68]. This was supported by a case study of brain malformation [69]. The NBPF transcript level was significantly correlated with neuroblastoma susceptibility and it is highly expressed in the fetal brain, suggesting that the gene plays an important role in the developing brain [70]. Interestingly, a recent study collected brain images of SCZ patients carrying different CNVs, including 1q21.1, 15q11.2, 16p11.2, 17q12 and 22q11.2, and found no changes in whole brain volume but significant alterations in several midline white-matter structures [71]. Chromosome 1q21.1 itself is associated with brain size, as significantly decreased brain size was obtained with deletions $(p<0.001)$ [72]. Particularly, the microcephalic effect was predominant in the temporo-parietal, hippocampal, olfactory and subcortical regions, as well as the posterior midbrain regions [72]. This feature had the interhemispheric effect that the altered brain size was restricted strongly in the right hemisphere [73].

\section{Molecular and Cellular Mechanisms Associated with 1q21.1 CNVs \\ 4.1. Effect Range of 1 q21.1 CNVs}

Studies of CNV pathogenesis have shown that deletions have deleterious effects, while duplications exhibit mild phenotypes [4]. Consistent with its pathogenicity, individuals with deletions have low fecundity and therefore undergo negative selection pressure $[74,75]$. These features of pathogenic CNVs appear in populations with low frequency and high mutation rates [8,74]. In light of this fact, it has become mainstream in genetic studies to distinguish distinct effect sizes in each ND. In line with the comparable burden of each 
structural variant, duplications exhibit a smaller burden than deletions in the synaptic pathway; functional clusters of duplications are enriched in NMDA receptor signaling, while functional clusters of deletions are enriched in the nervous system or behavioral phenotypes [15].

Examination of the cellular phenotype is a crucial step in the study of pathogenesis. Because many implicated risk genes in 1q21.1 CNVs are responsible for different cellular processes, including cell signaling, sensing and repair, impairment of these gene functions is expected to disrupt the cellular functions specifically involved with brain development and, in turn, to cause diseases [25]. However, a systematic pathological analysis of postmortem brains carrying 1q21.1 CNVs is still lacking. Due to the clinical manifestation reported among patients, animal models that mimic the genetic deficiency of 1q21.1 CNV could be good tools to provide some mechanistic insights and cellular and molecular targets for further therapeutic development $[8,72,76]$.

\subsection{Synaptic Signaling Pathway}

Genes for cell signaling are enriched in 1q21.1 [67]. Cell signaling in the brain is impeded by abnormal synaptic plasticity. The dopamine hypothesis has been proposed in many ND studies, including ASD [77] and SCZ [78,79]. A 1q21.1 deletion mouse model recapitulated the function of 1q21.1 CNV in cellular phenotypes [76]. The 1q21.1 $\mathrm{CNV}$ accounts for the increased sensitivity to psychostimulants (e.g., amphetamine) and increased dopamine cell firing, and hypersensitivity is not mediated by a different number of D1/D2 receptors [76]. Thus, the findings are consistent with previous studies showing that 1q21.1 deletion shows a higher prevalence in SCZ patients than in ASD [78].

Alteration of the potassium channel function can impair in the whole neural network. Disruption of potassium ion homeostasis often becomes an initiator of the cells' pathological cascade. In light of the crucial function of the potassium channel in neurodevelopment, GWAS has revealed a genetic overlap between rare risk CNVs (e.g., 1q21.1) and genes (e.g., KCNN3) encoding the potassium pump, transporter and channel [80-82]. The longer CAG repeats within the $K C N N 3$ gene seem to be associated with SCZ patients [81,82]. However, other studies did not confirm this association [83]. Interestingly, a mutant KCNN3 channel found in a SCZ patient was localized in the nucleus and inhibited the current mediated by another potassium channel, KCNN2 [84]. Therefore, the SCZ KCNN3 variant can function as a dominant-negative mutant to suppress endogenous small-conductance $\mathrm{K}$ currents and interfere with neuronal firing. Consistent with this notion, dysfunction in astrocyte differentiation derived from SCZ patient-derived induced pluripotent cells (iPSCs) was a result of excessive downregulation of potassium transporters in SCZ glia [80].

\subsection{Mitochondrial Functions}

Mitochondrial diseases are often associated with ASD children [85]; as a result, creatine kinase, ammonia and aspartate aminotransferase have been used biomarkers for mitochondrial dysfunction in ASD [86]; however, the scale of these studies is still small. In animal studies, AMP-activated protein kinase (AMPK) function is modulated by one of the highest correlated genes, PRKAB2 [25] in a Drosophila model of 1q21.1 [42]. A study confirmed that decreased AMPK activity impaired synaptic plasticity, which is critical for working memory and learning, and leads to sleep dysregulation and shortened lifespan [42]. Loss of AMPK activity also has been associated with the neurodegeneration phenotypes in a fly model of mitochondrial dysfunction [87]. Intriguingly, transcriptomic analyses of the three CNV mouse models-hemizygous deletions in corresponding regions of 1q21,15q13 and 22q11-have identified that neuronal mitochondrial genes are consistently downregulated across three mutant genotypes and are shared with the transcriptomic changes observed in both SCZ and ASD postmortem brains [88]. This study suggests a previously understudied mitochondrial hypothesis underlying neuropsychiatric diseases associated with CNVs $[89,90]$. 


\subsection{The WNT Signaling Pathway and BCL9}

Epidemiological studies have revealed that the prenatal period is vulnerable to ASD [91-96] and SCZ [97-105]. Among the key signaling pathways regulating fetal brain development, Wnt proteins play indispensable roles in angiogenesis [106-110], neurogenesis [111-118], cell survival [119-122], synaptogenesis [123-125] and neurite outgrowth [126,127]. The canonical pathway is well known to play a major role in neural development [128]. WNT signaling is regulated by several key components of the canonical Wnt pathway, including $\beta$-catenin, whose level determines the activity of canonical Wnt signaling. Recently, mutations in $\beta$-catenin have been identified as a frequent cause of ID (OMIM \#615075), known as CTNNB1 syndrome [129-134], with some individuals also being diagnosed with ASD [135-139]. CTNNB1 syndrome patients are characterized by low IQ, microcephaly and facial dysmorphism that cannot be attributed to a known clinical syndrome [129-134]. A $\beta$-catenin conditional KO mouse specifically in PV interneurons showed that $\beta$-cat $c K O$ mice have increased anxiety, impaired social interactions and elevated repetitive behaviors, which mimic some core symptoms of patients with ASD [140]. In addition, several mouse models with $\mathrm{KO}$ of Wnt regulators have shown consistent ASD-like behavioral deficits, including APC [141], DVL1 [142] and PTEN [143-146]. These data provide compelling evidence that an abnormal Wnt pathway is involved in the development of mental illness.

The BCL9 gene is located within the 1q21 region and encodes a nuclear retention factor for $\beta$-catenin, a critical part of the WNT signaling pathway [147-149]. BCL9 is essential for activation of the Wnt signaling in adult myogenic progenitors and regulates muscle regeneration [150]. To determine whether common variants in 1q21 can function as a candidate risk of SCZ, a large-scale GWAS comprising 5772 control and 4187 SCZ patients and 1135 patients with bipolar disorder was conducted in the Chinese Han population [47]. Interestingly, multiple SNPs within the BCL9 gene are significantly associated with SCZ. Consistently, other GWAS and integrative analyses suggest that $B C L 9$ is associated with negative symptoms in SCZ [151,152] and is one of top risk genes in CNV [153]. As disruption of the BCL9- $\beta$-catenin interaction inhibits Wnt activation [154], which has been proposed as a therapeutic target for cancer $[155,156]$, it remains to be tested if increasing BCL9 levels or fine-tuning WNT signaling could reverse the deficits caused by 1q21 CNV. In addition, several components of the Wnt signaling show an association with SCZ [157-161] and other psychiatric disorders [135,162,163]. Among the genetic factors associated with schizophrenia, the DISC1 [164] gene is a genetic risk factor for major mental illness [165-169]. DISC1 is a key regulator of NPC proliferation and mouse behavior through modulating the canonical Wnt signaling pathway [170]. DISC1 regulates cortical NPC proliferation and neuronal differentiation via inhibition of GSK3 $\beta$. Treatment with pharmacological inhibitors of GSK3 $\beta$ can completely ameliorate the DISC1 loss-of-functioninduced progenitor proliferation defects and behavioral abnormalities, which illustrates the exciting opportunity to develop small-molecule modulators of the Wnt pathway as prototypical drug treatments for psychiatric diseases.

\section{Discussion}

Genetics analysis has become a powerful tool to investigate the etiology of psychiatric disorders because many NDs show high inheritance and share a strong genetic correlation [61]. The CNV burden is pronounced in affected individuals [16,171]. However, the rare ( $<1 \%$ frequency) and large $(>500 \mathrm{kbp}) \mathrm{CNVs}$ in the $1 \mathrm{q} 21.1$ region are also found in unaffected individuals, which raises the question of whether microdeletions and microduplications of 1q21.1 are benign. Accumulative data showed that these variants were enriched in affected cases compared with unaffected ones, supporting that these variants contribute to the risk of disease [18]. However, the pathogenic CNVs were found with inconsistent patterns of inheritance and clinical phenotypes in family studies, which complicates predictions of genotype-phenotype correlations [10]. Nonetheless, active analyses of the genotype-phenotype association have revealed some possible linkages; for example, 
GJA5 and cardiac phenotypes [18], neurexins/neuroligins and synaptic differentiation [66], or ROBO1 and dyslexia [172].

As 1q21.1 CNV is strongly associated with developmental disabilities, the symptoms are severe in childhood, and the affecting range of 1q21.1 is different between adults and children $[35,63]$. However, a gap remains to compare severity in childhood $(<18$ year-olds) and adulthood ( $>18$-year-olds) within the same populations. Along with the general tendency of mild duplication phenotypes, there might be ascertainment bias in the clinical reports, in which mild duplications might have been overlooked or not been apparent in carriers at the moment of collecting data. Moreover, a possibility that mild psychiatric symptoms may have a late onset is another confounding factor. For a precise assessment, psychiatric evaluations in populations should be taken for the long term. The comparison studies reported that phonological processing and fine motor performance were significantly lower in microdeletion and microduplication probands considering only children and compared with adults $[35,173]$. This combined finding was confirmed in a 1q21.1 microduplication child with severe language and motor ability delay [172]. Besides the developmental stage, sex bias should be eliminated in sample collections for ND studies, especially ASD [174].

Profound and solid evidence with large controls and samples is required to refine the current findings. However, owing to the rarity of pathogenic CNVs in populations, current studies suffer from the limitation of acquiring a sufficient number of patients for each $\mathrm{CNV}$ type. This review discusses the specific CNV 1q21.1 as an important contributor in many psychiatric diseases.

\section{Conclusions}

There exist several limitations that hamper the validation of the GWAS findings. In order to investigate the etiology of a genetic disease, (i) a large sample size and (ii) examination of the molecular mechanism are required. The collective data, which include detailed clinical manifestations and genetic variations of individuals, like the type and number of CNVs as well as medical history, can consolidate observations of unique phenotypic patterns related to a certain genotype. However, there has been a difficulty obtain extensive pedigrees of probands of the disease due to its scarcity. It is unfortunate that a lot of research has been based on a limited sample size, usually less than 1000 patients. Along with clinical observations, verifying the molecular mechanism underlying the disease is critical. Animal models have come to be a useful tool, as they facilitate molecular observations that are impossible to assess directly from the human brain. However, the animal models do not fully satisfy the full extent of diagnostic symptoms in humans such as cognitive and internalizing symptoms. By the same token, there have not been sufficient animal models tested, owing to the difficulty of generating the replicated genetic rearrangements, especially 1q21.1 microduplications and neuropsychiatric symptoms in animals $[175,176]$. This can be complemented by using iPSCs [177]. Moreover, as most psychiatric disorders are polygenic, it is difficulty to declare that $1 \mathrm{q} 21.1 \mathrm{CNVs}$ are the single contributor of such phenotypes. In addition to the genetic factors, another pronounced contributor is the environment. Several studies have postulated that stress in early development and methylation can alter gene expression, producing an increased risk of develop the disease [178]. Moreover, even geographic exposure was found to be a factor among global populations [14].

Recently, ND research has moved to investigating the interaction between genetic variants and environmental factors and to find genetic convergence across the NDs [12]. A new direction is the association of neuroinflammation with NDs. A significant upregulation of microglial expression is observed in ASD and SCZ [179], and an imbalance of microglial activation is present with psychotic symptoms [180], suggesting another possible underlying mechanism [181]. As an emerging field in NDs [182], how neuroinflammation affects the penetrance and risk of rare CNVs in the diseases should be assessed in future studies. 
Author Contributions: J.Y. and Y.M. designed the study; J.Y. and Y.M. wrote the manuscript. All authors have read and agreed to the published version of the manuscript.

Funding: This work was supported by the National Institute of Mental Health of the National Institutes of Health under Award Number R21MH108983 and R01MH122556. The content is solely the responsibility of the authors and does not necessarily represent the official views of the NIH.

Institutional Review Board Statement: Not applicable.

Informed Consent Statement: Not applicable.

Data Availability Statement: Not applicable.

Acknowledgments: We thank Zifei Pei and Li Xu for their suggestions for the paper.

Conflicts of Interest: The authors declare no conflict of interest.

$\begin{array}{ll}\text { Abbreviations } \\ \text { ADHD } & \text { Attention deficit hyperactivity disorder } \\ \text { ASD } & \text { Autism spectrum disorder } \\ \text { BP } & \text { Breakpoint } \\ \text { CNV } & \text { Copy number variation } \\ \text { DD } & \text { Developmental delay } \\ \text { GWAS } & \text { Genome-wide association study } \\ \text { ID } & \text { Intellectual disorder } \\ \text { LCR } & \text { Low copy repeats } \\ \text { NAHR } & \text { Non-allelic homologous recombination } \\ \text { ND } & \text { Neurodevelopmental/neuropsychiatric disorder } \\ \text { SCZ } & \text { Schizophrenia } \\ \text { TAR } & \text { Thrombocytopenia-absent radius } \\ \text { NBPF } & \text { Neuroblastoma breakpoint family } \\ \text { NPC } & \text { Neural progenitor cell } \\ \text { KO } & \text { Knockout } \\ \text { PV } & \text { Parvalbumin } \\ \text { iPSCs } & \text { Induced pluripotent cells }\end{array}$

\section{References}

1. Girirajan, S.; Brkanac, Z.; Coe, B.P.; Baker, C.; Vives, L.; Vu, T.H.; Shafer, N.; Bernier, R.; Ferrero, G.B.; Silengo, M.; et al. Relative Burden of Large CNVs on a Range of Neurodevelopmental Phenotypes. PLoS Genet. 2011, 7, e1002334. [CrossRef]

2. Walsh, T.; McClellan, J.M.; McCarthy, S.E.; Addington, A.M.; Pierce, S.B.; Cooper, G.M.; Nord, A.S.; Kusenda, M.; Malhotra, D.; Bhandari, A.; et al. Rare Structural Variants Disrupt Multiple Genes in Neurodevelopmental Pathways in Schizophrenia. Science 2008, 320, 539-543. [CrossRef]

3. Kaminsky, E.B.; Kaul, V.; Paschall, J.; Church, D.M.; Bunke, B.; Kunig, D.; Moreno-De-Luca, D.; Moreno-De-Luca, A.; Mulle, J.G.; Warren, S.T.; et al. An evidence-based approach to establish the functional and clinical significance of copy number variants in intellectual and developmental disabilities. Genet. Med. 2011, 13, 777-784. [CrossRef]

4. Girirajan, S.; Rosenfeld, J.A.; Coe, B.P.; Parikh, S.; Friedman, N.; Goldstein, A.; Filipink, R.A.; McConnell, J.S.; Angle, B.; Meschino, W.S.; et al. Phenotypic Heterogeneity of Genomic Disorders and Rare Copy-Number Variants. N. Engl. J. Med. 2012, 367, 1321-1331. [CrossRef]

5. Guyatt, A.L.; Stergiakouli, E.; Martin, J.; Walters, J.; O’Donovan, M.; Owen, M.; Thapar, A.; Kirov, G.; Rodriguez, S.; Rai, D.; et al. Association of copy number variation across the genome with neuropsychiatric traits in the general population. Am. J. Med. Genet. Part B Neuropsychiatr. Genet. 2018, 177, 489-502. [CrossRef]

6. Coe, B.P.; Girirajan, S.; Eichler, E.E. The genetic variability and commonality of neurodevelopmental disease. Am. J. Med. Genet. Part C Semin. Med. Genet. 2012, 160C, 118-129. [CrossRef]

7. Forsingdal, A.; Jørgensen, T.N.; Olsen, L.; Werge, T.; Didriksen, M.; Nielsen, J. Can Animal Models of Copy Number Variants That Predispose to Schizophrenia Elucidate Underlying Biology? Biol. Psychiatry 2019, 85, 13-24. [CrossRef]

8. Stefansson, H.; Rujescu, D.; Cichon, S.; Pietiläinen, O.P.H.; Ingason, A.; Steinberg, S.; Fossdal, R.; Sigurdsson, E.; Sigmundsson, T.; Buizer-Voskamp, J.E.; et al. Large recurrent microdeletions associated with schizophrenia. Nature 2008, 455, 232-236. [CrossRef]

9. Stone, J.L.; O’Donovan, M.C.; Gurling, H.; Kirov, G.K.; Blackwood, D.H.R.; Corvin, A.; Craddock, N.J.; Gill, M.; Hultman, C.M.; Lichtenstein, P.; et al. Rare chromosomal deletions and duplications increase risk of schizophrenia. Nature 2008, 455, 237-241. [CrossRef] 
10. Kirov, G.; Rees, E.; Walters, J.T.R.; Escott-Price, V.; Georgieva, L.; Richards, A.L.; Chambert, K.D.; Davies, G.; Legge, S.E.; Moran, J.L.; et al. The Penetrance of Copy Number Variations for Schizophrenia and Developmental Delay. Biol. Psychiatry 2014, 75, 378-385. [CrossRef]

11. Girirajan, S.; Rosenfeld, J.A.; Cooper, G.M.; Antonacci, F.; Siswara, P.; Itsara, A.; Vives, L.; Walsh, T.; McCarthy, S.E.; Baker, C.; et al. A recurrent 16p12.1 microdeletion supports a two-hit model for severe developmental delay. Nat. Genet. 2010, 42, 203-209. [CrossRef]

12. Sriretnakumar, V.; Zai, C.C.; Wasim, S.; Barsanti-Innes, B.; Kennedy, J.L.; So, J. Copy number variant syndromes are frequent in schizophrenia: Progressing towards a CNV-schizophrenia model. Schizophr. Res. 2019, 209, 171-178. [CrossRef]

13. Rees, E.; Walters, J.T.R.; Georgieva, L.; Isles, A.R.; Chambert, K.D.; Richards, A.L.; Mahoney-Davies, G.; Legge, S.E.; Moran, J.L.; McCarroll, S.A.; et al. Analysis of copy number variations at 15 schizophrenia-associated loci. Br. J. Psychiatry 2014, 204, 108-114. [CrossRef]

14. Takumi, T.; Tamada, K. CNV biology in neurodevelopmental disorders. Curr. Opin. Neurobiol. 2018, 48, 183-192. [CrossRef]

15. Zhuo, C.; Hou, W.; Lin, C.; Hu, L.; Li, J. Potential Value of Genomic Copy Number Variations in Schizophrenia. Front. Mol. Neurosci. 2017, 10. [CrossRef] [PubMed]

16. Marshall, C.R.; Howrigan, D.P.; Merico, D.; Thiruvahindrapuram, B.; Wu, W.; Greer, D.S.; Antaki, D.; Shetty, A.; Holmans, P.A.; Pinto, D.; et al. Contribution of copy number variants to schizophrenia from a genome-wide study of 41,321 subjects. Nat. Genet. 2017, 49, 27-35. [CrossRef]

17. Sanders, S.J.; Ercan-Sencicek, A.G.; Hus, V.; Luo, R.; Murtha, M.T.; Moreno-De-Luca, D.; Chu, S.H.; Moreau, M.P.; Gupta, A.R.; Thomson, S.A.; et al. Multiple recurrent de novo CNVs, including duplications of the 7q11. 23 Williams syndrome region, are strongly associated with autism. Neuron 2011, 70, 863-885. [CrossRef]

18. Mefford, H.C.; Sharp, A.J.; Baker, C.; Itsara, A.; Jiang, Z.; Buysse, K.; Huang, S.; Maloney, V.K.; Crolla, J.A.; Baralle, D.; et al. Recurrent Rearrangements of Chromosome 1q21.1 and Variable Pediatric Phenotypes. N. Engl. J. Med. 2008, 359, 1685-1699. [CrossRef]

19. Sullivan, P.F. Schizophrenia and the dynamic genome. Genome Med. 2017, 9, 22. [CrossRef]

20. Malhotra, D.; Sebat, J. CNVs: Harbingers of a Rare Variant Revolution in Psychiatric Genetics. Cell 2012, $148,1223-1241$. [CrossRef]

21. Brunetti-Pierri, N.; Berg, J.S.; Scaglia, F.; Belmont, J.; Bacino, C.A.; Sahoo, T.; Lalani, S.R.; Graham, B.; Lee, B.; Shinawi, M.; et al. Recurrent reciprocal 1q21.1 deletions and duplications associated with microcephaly or macrocephaly and developmental and behavioral abnormalities. Nat. Genet. 2008, 40, 1466-1471. [CrossRef]

22. Owen, M.J. Implications of Genetic Findings for Understanding Schizophrenia. Schizophr. Bull. 2012, 38, 904-907. [CrossRef]

23. Haldeman-Englert, C.; Jewett, T. 1q21.1 Microdeletion; University of Washington: Seattle, WA, USA, $1993-2021$.

24. Ripke, S.; O’Dushlaine, C.; Chambert, K.; Moran, J.L.; Kahler, A.K.; Akterin, S.; Bergen, S.E.; Collins, A.L.; Crowley, J.J.; Fromer, M.; et al. Genome-wide association analysis identifies 13 new risk loci for schizophrenia. Nat. Genet. 2013, 45, 1150-1159. [CrossRef]

25. Harvard, C.; Strong, E.; Mercier, E.; Colnaghi, R.; Alcantara, D.; Chow, E.; Martell, S.; Tyson, C.; Hrynchak, M.; McGillivray, B.; et al. Understanding the impact of 1q21.1 copy number variant. Orphanet. J. Rare Dis. 2011, 6, 54. [CrossRef] [PubMed]

26. Torres, F.; Barbosa, M.; Maciel, P. Recurrent copy number variations as risk factors for neurodevelopmental disorders: Critical overview and analysis of clinical implications. J. Med. Genet. 2016, 53, 73-90. [CrossRef]

27. Albers, C.A.; Paul, D.S.; Schulze, H.; Freson, K.; Stephens, J.C.; Smethurst, P.A.; Jolley, J.D.; Cvejic, A.; Kostadima, M.; Bertone, P.; et al. Compound inheritance of a low-frequency regulatory SNP and a rare null mutation in exon-junction complex subunit RBM8A causes TAR syndrome. Nat. Genet. 2012, 44, 435-439. [CrossRef] [PubMed]

28. Skorka, A.; Bielicka-Cymermann, J.; Gieruszczak-Bialek, D.; Korniszewski, L. Thrombocytopenia-absent radius (tar) syndrome: A case with agenesis of corpus callosum, hypoplasia of cerebellar vermis and horseshoe kidney. Genet. Couns. 2005, 16, 377-382.

29. Weiss Sachdev, S.; Sunde, R.A. Selenium regulation of transcript abundance and translational efficiency of glutathione peroxidase1 and -4 in rat liver. Biochem. J. 2001, 357, 851-858. [CrossRef]

30. Ceylan, A.C.; Sahin, I.; Erdem, H.B.; Kayhan, G.; Simsek-Kiper, P.O.; Utine, G.E.; Percin, F.; Boduroglu, K.; Alikasifoglu, M. An eight-case 1q21 region series: Novel aberrations and clinical variability with new features. J. Intellect. Disabil. Res. 2019, 63, 548-557. [CrossRef]

31. Mao, H.; Pilaz, L.-J.; McMahon, J.J.; Golzio, C.; Wu, D.; Shi, L.; Katsanis, N.; Silver, D.L. Rbm8a Haploinsufficiency Disrupts Embryonic Cortical Development Resulting in Microcephaly. J. Neurosci. 2015, 35, 7003-7018. [CrossRef]

32. Zou, D.; McSweeney, C.; Sebastian, A.; Reynolds, D.J.; Dong, F.; Zhou, Y.; Deng, D.; Wang, Y.; Liu, L.; Zhu, J.; et al. A critical role of RBM8a in proliferation and differentiation of embryonic neural progenitors. Neural. Dev. 2015, 10, 18. [CrossRef]

33. McSweeney, C.; Dong, F.; Chen, M.; Vitale, J.; Xu, L.; Crowley, N.; Luscher, B.; Zou, D.; Mao, Y. Full function of exon junction complex factor, Rbm8a, is critical for interneuron development. Transl. Psychiatry 2020, 10, 379. [CrossRef]

34. Alachkar, A.; Jiang, D.; Harrison, M.; Zhou, Y.; Chen, G.; Mao, Y. An EJC factor RBM8a Regulates Anxiety Behaviors. Curr. Mol. Med. 2013, 13, 887-899. [CrossRef]

35. Bernier, R.; Steinman, K.J.; Reilly, B.; Wallace, A.S.; Sherr, E.H.; Pojman, N.; Mefford, H.C.; Gerdts, J.; Earl, R.; Hanson, E.; et al. Clinical phenotype of the recurrent 1q21.1 copy-number variant. Genet. Med. 2016, 18, 341-349. [CrossRef]

36. Busè, M.; Cuttaia, H.C.; Palazzo, D.; Mazara, M.V.; Lauricella, S.A.; Malacarne, M.; Pierluigi, M.; Cavani, S.; Piccione, M. Expanding the phenotype of reciprocal 1q21.1 deletions and duplications: A case series. Ital. J. Pediatrics 2017, 43, 61. [CrossRef] 
37. Golzio, C.; Katsanis, N. Genetic architecture of reciprocal CNVs. Curr. Opin. Genet. Dev. 2013, 23, 240-248. [CrossRef]

38. Hall, J.; Trent, S.; Thomas, K.L.; O’Donovan, M.C.; Owen, M.J. Genetic Risk for Schizophrenia: Convergence on Synaptic Pathways Involved in Plasticity. Biol. Psychiatry 2015, 77, 52-58. [CrossRef] [PubMed]

39. Deshpande, A.; Weiss, L.A. Recurrent reciprocal copy number variants: Roles and rules in neurodevelopmental disorders. Dev. Neurobiol. 2018, 78, 519-530. [CrossRef]

40. Crespi, B.J.; Crofts, H.J. Association testing of copy number variants in schizophrenia and autism spectrum disorders. J. Neurodev. Disord. 2012, 4, 15. [CrossRef]

41. Warde-Farley, D.; Donaldson, S.L.; Comes, O.; Zuberi, K.; Badrawi, R.; Chao, P.; Franz, M.; Grouios, C.; Kazi, F.; Lopes, C.T.; et al. The GeneMANIA prediction server: Biological network integration for gene prioritization and predicting gene function. Nucleic Acids Res. 2010, 38, W214-W220. [CrossRef]

42. Nagy, S.; Maurer, G.W.; Hentze, J.L.; Rose, M.; Werge, T.M.; Rewitz, K. AMPK signaling linked to the schizophrenia-associated 1q21.1 deletion is required for neuronal and sleep maintenance. PLoS Genet. 2018, 14, e1007623. [CrossRef]

43. Rong, P.; Wang, X.; Niesman, I.; Wu, Y.; Benedetti, L.E.; Dunia, I.; Levy, E.; Gong, X. Disruption of ja8 ( $\alpha 8$ connexin) in mice leads to microphthalmia associated with retardation of lens growth and lens fiber maturation. Development 2002, 129, 167-174. [CrossRef]

44. Ni, X.; Valente, J.; Azevedo, M.H.; Pato, M.T.; Pato, C.N.; Kennedy, J.L. Connexin 50 gene on human chromosome 1q21 is associated with schizophrenia in matched case-control and family-based studies. J. Med Genet. 2007, 44, 532-536. [CrossRef]

45. Verhagen, J.M.A.; de Leeuw, N.; Papatsonis, D.N.M.; Grijseels, E.W.M.; de Krijger, R.R.; Wessels, M.W. Phenotypic Variability Associated with a Large Recurrent 1q21.1 Microduplication in a Three-Generation Family. Mol. Syndromol. 2015, 6, 71-76. [CrossRef]

46. Simon, A.M.; Goodenough, D.A.; Paul, D.L. Mice lacking connexin40 have cardiac conduction abnormalities characteristic of atrioventricular block and bundle branch block. Curr. Biol. 1998, 8, 295-298. [CrossRef]

47. Li, J.; Zhou, G.; Ji, W.; Feng, G.; Zhao, Q.; Liu, J.; Li, T.; Li, Y.; Chen, P.; Zeng, Z.; et al. Common Variants in the BCL9 Gene Conferring Risk of Schizophrenia. Arch. Gen. Psychiatry 2011, 68, 232-240. [CrossRef] [PubMed]

48. Varshavi, D.; Scott, F.H.; Varshavi, D.; Veeravalli, S.; Phillips, I.R.; Veselkov, K.; Strittmatter, N.; Takats, Z.; Shephard, E.A.; Everett, J.R. Metabolic Biomarkers of Ageing in C57BL/6J Wild-Type and Flavin-Containing Monooxygenase 5 (FMO5)-Knockout Mice. Front. Mol. Biosci. 2018, 5, 28. [CrossRef]

49. Gagliardi, S.; Abel, K.; Bianchi, M.; Milani, P.; Bernuzzi, S.; Corato, M.; Ceroni, M.; Cashman, J.R.; Cereda, C. Regulation of FMO and PON Detoxication Systems in ALS Human Tissues. Neurotox. Res. 2013, 23, 370-377. [CrossRef]

50. Pang, H.; Yu, X.; Kim, Y.M.; Wang, X.; Jinkins, J.K.; Yin, J.; Li, S.; Gu, H. Disorders Associated With Diverse, Recurrent Deletions and Duplications at 1q21.1. Front. Genet. 2020, 11. [CrossRef]

51. Rosenfeld, J.A.; Traylor, R.N.; Schaefer, G.B.; McPherson, E.W.; Ballif, B.C.; Klopocki, E.; Mundlos, S.; Shaffer, L.G.; Aylsworth, A.S. Proximal microdeletions and microduplications of $1 \mathrm{q} 21.1$ contribute to variable abnormal phenotypes. Eur. J. Hum. Genet. 2012, 20, 754-761. [CrossRef]

52. Dickson, H.; Laurens, K.R.; Cullen, A.E.; Hodgins, S. Meta-analyses of cognitive and motor function in youth aged 16 years and younger who subsequently develop schizophrenia. Psychol. Med. 2012, 42, 743-755. [CrossRef] [PubMed]

53. Donoghue, K.; Medley, I.; Brewin, J.; Glazebrook, C.; Mason, P.; Cantwell, R.; Jones, P.B.; Harrison, G.; Doody, G.A. The association between substance misuse and first-episode psychosis in a defined UK geographical area during the 1990s. Soc. Psychiatry Psychiatr. Epidemiol. 2011, 46, 137-142. [CrossRef]

54. Compton, M.T.; Kelley, M.E.; Ramsay, C.E.; Pringle, M.; Goulding, S.M.; Esterberg, M.L.; Stewart, T.; Walker, E.F. Association of pre-onset cannabis, alcohol, and tobacco use with age at onset of prodrome and age at onset of psychosis in first-episode patients. Am. J. Psychiatry 2009, 166, 1251-1257. [CrossRef]

55. Foti, D.J.; Kotov, R.; Guey, L.T.; Bromet, E.J. Cannabis use and the course of schizophrenia: 10-year follow-up after first hospitalization. Am. J. Psychiatry 2010, 167, 987-993. [CrossRef] [PubMed]

56. Kerfoot, K.E.; Rosenheck, R.A.; Petrakis, I.L.; Swartz, M.S.; Keefe, R.S.; McEvoy, J.P.; Stroup, T.S. Substance use and schizophrenia: Adverse correlates in the CATIE study sample. Schizophr. Res. 2011, 132, 177-182. [CrossRef]

57. Whiteford, H.A.; Degenhardt, L.; Rehm, J.; Baxter, A.J.; Ferrari, A.J.; Erskine, H.E.; Charlson, F.J.; Norman, R.E.; Flaxman, A.D.; Johns, N.; et al. Global burden of disease attributable to mental and substance use disorders: Findings from the Global Burden of Disease Study 2010. Lancet 2013. [CrossRef]

58. Batki, S.L.; Meszaros, Z.S.; Strutynski, K.; Dimmock, J.A.; Leontieva, L.; Ploutz-Snyder, R.; Canfield, K.; Drayer, R.A. Medical comorbidity in patients with schizophrenia and alcohol dependence. Schizophr. Res. 2009, 107, 139-146. [CrossRef]

59. Van Steensel, F.J.; Bogels, S.M.; Perrin, S. Anxiety disorders in children and adolescents with autistic spectrum disorders: A meta-analysis. Clin. Child Fam. Psychol. Rev. 2011, 14, 302-317. [CrossRef]

60. Williams, D.L.; Goldstein, G.; Minshew, N.J. The profile of memory function in children with autism. Neuropsychology 2006, 20, 21-29. [CrossRef] [PubMed]

61. Lee, P.H.; Anttila, V.; Won, H.; Feng, Y.-C.A.; Rosenthal, J.; Zhu, Z.; Tucker-Drob, E.M.; Nivard, M.G.; Grotzinger, A.D.; Posthuma, D.; et al. Genomic Relationships, Novel Loci, and Pleiotropic Mechanisms across Eight Psychiatric Disorders. Cell 2019, 179, 1469-1482.e1411. [CrossRef] [PubMed] 
62. Kendall, K.M.; Rees, E.; Bracher-Smith, M.; Legge, S.; Riglin, L.; Zammit, S.; O’Donovan, M.C.; Owen, M.J.; Jones, I.; Kirov, G.; et al. Association of Rare Copy Number Variants With Risk of Depression. JAMA 2019, 76, 818-825. [CrossRef]

63. Dolcetti, A.; Silversides, C.K.; Marshall, C.R.; Lionel, A.C.; Stavropoulos, D.J.; Scherer, S.W.; Bassett, A.S. 1q21.1 Microduplication expression in adults. Genet. Med. 2013, 15, 282-289. [CrossRef]

64. Gudmundsson, O.O.; Walters, G.B.; Ingason, A.; Johansson, S.; Zayats, T.; Athanasiu, L.; Sonderby, I.E.; Gustafsson, O.; Nawaz, M.S.; Jonsson, G.F.; et al. Attention-deficit hyperactivity disorder shares copy number variant risk with schizophrenia and autism spectrum disorder. Transl. Psychiatry 2019, 9, 258. [CrossRef]

65. Basel-Vanagaite, L.; Goldberg-Stern, H.; Mimouni-Bloch, A.; Shkalim, V.; Böhm, D.; Kohlhase, J. An Emerging 1q21.1 DeletionAssociated Neurodevelopmental Phenotype. J. Child Neurol. 2011, 26, 113-116. [CrossRef]

66. Szatmari, P.; Paterson, A.D.; Zwaigenbaum, L.; Roberts, W.; Brian, J.; Liu, X.-Q.; Vincent, J.B.; Skaug, J.L.; Thompson, A.P.; Senman, L.; et al. Mapping autism risk loci using genetic linkage and chromosomal rearrangements. Nat. Genet. 2007, 39, 319-328. [CrossRef]

67. Sanders, S.J.; He, X.; Willsey, A.J.; Ercan-Sencicek, A.G.; Samocha, K.E.; Cicek, A.E.; Murtha, M.T.; Bal, V.H.; Bishop, S.L.; Dong, S.; et al. Insights into Autism Spectrum Disorder Genomic Architecture and Biology from 71 Risk Loci. Neuron 2015, 87, 1215-1233. [CrossRef]

68. Dumas, L.J.; O’Bleness, M.S.; Davis, J.M.; Dickens, C.M.; Anderson, N.; Keeney, J.G.; Jackson, J.; Sikela, M.; Raznahan, A.; Giedd, J.; et al. DUF1220-Domain Copy Number Implicated in Human Brain-Size Pathology and Evolution. Am. J. Hum. Genet. 2012, 91, 444-454. [CrossRef]

69. Milone, R.; Valetto, A.; Battini, R.; Bertini, V.; Valvo, G.; Cioni, G.; Sicca, F. Focal cortical dysplasia, microcephaly and epilepsy in a boy with 1q21.1-q21.3 duplication. Eur. J. Med. Genet. 2016, 59, 278-282. [CrossRef]

70. Diskin, S.J.; Hou, C.; Glessner, J.T.; Attiyeh, E.F.; Laudenslager, M.; Bosse, K.; Cole, K.; Mossé, Y.P.; Wood, A.; Lynch, J.E.; et al. Copy number variation at 1q21.1 associated with neuroblastoma. Nature 2009, 459, 987-991. [CrossRef]

71. Drakesmith, M.; Parker, G.D.; Smith, J.; Linden, S.C.; Rees, E.; Williams, N.; Owen, M.J.; van den Bree, M.; Hall, J.; Jones, D.K.; et al. Genetic risk for schizophrenia and developmental delay is associated with shape and microstructure of midline white-matter structures. Transl. Psychiatry 2019, 9, 102. [CrossRef]

72. Reinwald, J.R.; Sartorius, A.; Weber-Fahr, W.; Sack, M.; Becker, R.; Didriksen, M.; Stensbøl, T.B.; Schwarz, A.J.; Meyer-Lindenberg, A.; Gass, N. Separable neural mechanisms for the pleiotropic association of copy number variants with neuropsychiatric traits. Transl. Psychiatry 2020, 10, 93. [CrossRef] [PubMed]

73. Warland, A.; Kendall, K.M.; Rees, E.; Kirov, G.; Caseras, X. Schizophrenia-associated genomic copy number variants and subcortical brain volumes in the UK Biobank. Mol. Psychiatry 2020, 25, 854-862. [CrossRef]

74. Rees, E.; Moskvina, V.; Owen, M.J.; O’Donovan, M.C.; Kirov, G. De Novo Rates and Selection of Schizophrenia-Associated Copy Number Variants. Biol. Psychiatry 2011, 70, 1109-1114. [CrossRef] [PubMed]

75. Kirov, G.; Pocklington, A.J.; Holmans, P.; Ivanov, D.; Ikeda, M.; Ruderfer, D.; Moran, J.; Chambert, K.; Toncheva, D.; Georgieva, L.; et al. De novo CNV analysis implicates specific abnormalities of postsynaptic signalling complexes in the pathogenesis of schizophrenia. Mol. Psychiatry 2012, 17, 142-153. [CrossRef] [PubMed]

76. Nielsen, J.; Fejgin, K.; Sotty, F.; Nielsen, V.; Mørk, A.; Christoffersen, C.T.; Yavich, L.; Lauridsen, J.B.; Clausen, D.; Larsen, P.H.; et al. A mouse model of the schizophrenia-associated 1q21.1 microdeletion syndrome exhibits altered mesolimbic dopamine transmission. Transl. Psychiatry 2017, 7, 1261. [CrossRef]

77. Marotta, R.; Risoleo, M.C.; Messina, G.; Parisi, L.; Carotenuto, M.; Vetri, L.; Roccella, M. The Neurochemistry of Autism. Brain Sci. 2020, 10, 163. [CrossRef]

78. Howes, O.D.; Kambeitz, J.; Kim, E.; Stahl, D.; Slifstein, M.; Abi-Dargham, A.; Kapur, S. The Nature of Dopamine Dysfunction in Schizophrenia and What This Means for Treatment: Meta-analysis of Imaging Studies. Arch. Gen. Psychiatry 2012, 69, 776-786. [CrossRef]

79. Howes, O.D.; Shotbolt, P.; Bloomfield, M.; Daalman, K.; Demjaha, A.; Diederen, K.M.J.; Ibrahim, K.; Kim, E.; McGuire, P.; Kahn, R.S.; et al. Dopaminergic Function in the Psychosis Spectrum: An [18F]-DOPA Imaging Study in Healthy Individuals with Auditory Hallucinations. Schizophr. Bull. 2013, 39, 807-814. [CrossRef]

80. Liu, Z.; Osipovitch, M.; Benraiss, A.; Huynh, N.P.T.; Foti, R.; Bates, J.; Chandler-Militello, D.; Findling, R.L.; Tesar, P.J.; Nedergaard, M.; et al. Dysregulated Glial Differentiation in Schizophrenia May Be Relieved by Suppression of SMAD4- and REST-Dependent Signaling. Cell Rep. 2019, 27, 3832-3843.e3836. [CrossRef]

81. Dror, V.; Shamir, E.; Ghanshani, S.; Kimhi, R.; Swartz, M.; Barak, Y.; Weizman, R.; Avivi, L.; Litmanovitch, T.; Fantino, E.; et al. hKCa3/KCNN3 potassium channel gene: Association of longer CAG repeats with schizophrenia in Israeli Ashkenazi Jews, expression in human tissues and localization to chromosome 1q21. Mol. Psychiatry 1999, 4, 254-260. [CrossRef]

82. Austin, C.P.; Holder, D.J.; Ma, L.; Mixson, L.A.; Caskey, C.T. Mapping of hKCa3 to chromosome 1q21 and investigation of linkage of CAG repeat polymorphism to schizophrenia. Mol. Psychiatry 1999, 4, 261-266. [CrossRef]

83. Meissner, B.; Purmann, S.; Schürmann, M.; Zühlke, C.; Lencer, R.; Arolt, V.; Müller-Myhsok, B.; Morris-Rosendahl, D.J.; Schwinger, E. hSKCa3: A candidate gene for schizophrenia? Psychiatr. Genet. 1999, 9, 91-96. [CrossRef]

84. Miller, M.J.; Rauer, H.; Tomita, H.; Rauer, H.; Gargus, J.J.; Gutman, G.A.; Cahalan, M.D.; Chandy, K.G. Nuclear Localization and Dominant-negative Suppression by a Mutant SKCa3 N-terminal Channel Fragment Identified in a Patient with Schizophrenia. J. Biol. Chem. 2001, 276, 27753-27756. [CrossRef] 
85. Frye, R.E.; Vassall, S.; Kaur, G.; Lewis, C.; Karim, M.; Rossignol, D. Emerging biomarkers in autism spectrum disorder: A systematic review. Ann. Transl. Med. 2019, 7, 792. [CrossRef] [PubMed]

86. Rossignol, D.A.; Frye, R.E. Mitochondrial dysfunction in autism spectrum disorders: A systematic review and meta-analysis. Mol. Psychiatry 2012, 17, 290-314. [CrossRef]

87. Ng, C.-H.; Guan, M.S.H.; Koh, C.; Ouyang, X.; Yu, F.; Tan, E.-K.; O’Neill, S.P.; Zhang, X.; Chung, J.; Lim, K.-L. AMP Kinase Activation Mitigates Dopaminergic Dysfunction and Mitochondrial Abnormalities in Drosophila Models of Parkinson's Disease. J. Neurosci. 2012, 32, 14311-14317. [CrossRef]

88. Gordon, A.; Forsingdal, A.; Klewe, I.V.; Nielsen, J.; Didriksen, M.; Werge, T.; Geschwind, D.H. Transcriptomic networks implicate neuronal energetic abnormalities in three mouse models harboring autism and schizophrenia-associated mutations. Mol. Psychiatry 2019. [CrossRef]

89. Prabakaran, S.; Swatton, J.E.; Ryan, M.M.; Huffaker, S.J.; Huang, J.-J.; Griffin, J.L.; Wayland, M.; Freeman, T.; Dudbridge, F.; Lilley, K.S.; et al. Mitochondrial dysfunction in schizophrenia: Evidence for compromised brain metabolism and oxidative stress. Mol. Psychiatry 2004, 9, 684-697. [CrossRef]

90. Roberts, R.C. Mitochondrial dysfunction in schizophrenia: With a focus on postmortem studies. Mitochondrion 2021, 56, 91-101. [CrossRef]

91. Sunyer, J.; Dadvand, P. Pre-natal brain development as a target for urban air pollution. Basic Clin. Pharmacol. Toxicol. 2019, 125, 81-88. [CrossRef]

92. Windham, G.C.; Pearl, M.; Poon, V.; Berger, K.; Soriano, J.W.; Eyles, D.; Lyall, K.; Kharrazi, M.; Croen, L.A. Maternal Vitamin D Levels During Pregnancy in Association With Autism Spectrum Disorders (ASD) or Intellectual Disability (ID) in Offspring; Exploring Non-linear Patterns and Demographic Sub-groups. Autism. Res. 2020, 13, 2216-2229. [CrossRef] [PubMed]

93. Jones, H.F.; Ho, A.C.C.; Sharma, S.; Mohammad, S.S.; Kothur, K.; Patel, S.; Brilot, F.; Guastella, A.J.; Dale, R.C.; Group, I.-N.S. Maternal thyroid autoimmunity associated with acute-onset neuropsychiatric disorders and global regression in offspring. Dev. Med. Child Neurol. 2019, 61, 984-988. [CrossRef]

94. Van den Bergh, B.R.H.; van den Heuvel, M.I.; Lahti, M.; Braeken, M.; de Rooij, S.R.; Entringer, S.; Hoyer, D.; Roseboom, T.; Räikkönen, K.; King, S.; et al. Prenatal developmental origins of behavior and mental health: The influence of maternal stress in pregnancy. Neurosci. Biobehav. Rev. 2020, 117, 26-64. [CrossRef]

95. Webb, S.J.; Garrison, M.M.; Bernier, R.; McClintic, A.M.; King, B.H.; Mourad, P.D. Severity of ASD symptoms and their correlation with the presence of copy number variations and exposure to first trimester ultrasound. Autism Res. 2017, 10, 472-484. [CrossRef] [PubMed]

96. Shelton, J.F.; Geraghty, E.M.; Tancredi, D.J.; Delwiche, L.D.; Schmidt, R.J.; Ritz, B.; Hansen, R.L.; Hertz-Picciotto, I. Neurodevelopmental Disorders and Prenatal Residential Proximity to Agricultural Pesticides: The CHARGE Study. Environ. Health Perspect. 2014, 122, 1103-1109. [CrossRef]

97. Pedersen, M.G.; Stevens, H.; Pedersen, C.B.; Norgaard-Pedersen, B.; Mortensen, P.B. Toxoplasma infection and later development of schizophrenia in mothers. Am. J. Psychiatry 2011, 168, 814-821. [CrossRef]

98. Dickerson, F.; Kirkpatrick, B.; Boronow, J.; Stallings, C.; Origoni, A.; Yolken, R. Deficit schizophrenia: Association with serum antibodies to cytomegalovirus. Schizophr. Bull. 2006, 32, 396-400. [CrossRef]

99. O'Callaghan, E.; Sham, P.; Takei, N.; Glover, G.; Murray, R.M. Schizophrenia after prenatal exposure to 1957 A2 influenza epidemic. Lancet 1991, 337, 1248-1250. [CrossRef]

100. Suvisaari, J.; Haukka, J.; Tanskanen, A.; Hovi, T.; Lonnqvist, J. Association between prenatal exposure to poliovirus infection and adult schizophrenia. Am. J. Psychiatry 1999, 156, 1100-1102.

101. Susser, E.S.; Lin, S.P. Schizophrenia after prenatal exposure to the Dutch Hunger Winter of 1944-1945. Arch. Gen. Psychiatry 1992, 49, 983-988. [CrossRef]

102. St Clair, D.; Xu, M.; Wang, P.; Yu, Y.; Fang, Y.; Zhang, F.; Zheng, X.; Gu, N.; Feng, G.; Sham, P.; et al. Rates of adult schizophrenia following prenatal exposure to the Chinese famine of 1959-1961. JAMA 2005, 294, 557-562. [CrossRef]

103. Shen, Q.; Li, Z.Q.; Sun, Y.; Wang, T.; Wan, C.L.; Li, X.W.; Zhao, X.Z.; Feng, G.Y.; Li, S.; St Clair, D.; et al. The role of proinflammatory factors in mediating the effects on the fetus of prenatal undernutrition: Implications for schizophrenia. Schizophr. Res. 2008, 99, 48-55. [CrossRef] [PubMed]

104. O'Donnell, K.; O'Connor, T.G.; Glover, V. Prenatal stress and neurodevelopment of the child: Focus on the HPA axis and role of the placenta. Dev. Neurosci. 2009, 31, 285-292. [CrossRef]

105. Jablensky, A.V.; Morgan, V.; Zubrick, S.R.; Bower, C.; Yellachich, L.A. Pregnancy, delivery, and neonatal complications in a population cohort of women with schizophrenia and major affective disorders. Am. J. Psychiatry 2005, 162, 79-91. [CrossRef] [PubMed]

106. Gradinaru, V.; Zhang, F.; Ramakrishnan, C.; Mattis, J.; Prakash, R.; Diester, I.; Goshen, I.; Thompson, K.R.; Deisseroth, K. Molecular and cellular approaches for diversifying and extending optogenetics. Cell 2010, 141, 154-165. [CrossRef]

107. Junge, H.J.; Yang, S.; Burton, J.B.; Paes, K.; Shu, X.; French, D.M.; Costa, M.; Rice, D.S.; Ye, W. TSPAN12 regulates retinal vascular development by promoting Norrin- but not Wnt-induced FZD4/beta-catenin signaling. Cell 2009, 139, 299-311. [CrossRef]

108. Ye, X.; Wang, Y.; Cahill, H.; Yu, M.; Badea, T.C.; Smallwood, P.M.; Peachey, N.S.; Nathans, J. Norrin, frizzled-4, and Lrp5 signaling in endothelial cells controls a genetic program for retinal vascularization. Cell 2009, 139, 285-298. [CrossRef] 
109. Phng, L.K.; Potente, M.; Leslie, J.D.; Babbage, J.; Nyqvist, D.; Lobov, I.; Ondr, J.K.; Rao, S.; Lang, R.A.; Thurston, G.; et al. Nrarp coordinates endothelial Notch and Wnt signaling to control vessel density in angiogenesis. Dev. Cell 2009, 16, 70-82. [CrossRef] [PubMed]

110. Daneman, R.; Agalliu, D.; Zhou, L.; Kuhnert, F.; Kuo, C.J.; Barres, B.A. Wnt/beta-catenin signaling is required for CNS, but not non-CNS, angiogenesis. Proc. Natl. Acad. Sci. USA 2009, 106, 641-646. [CrossRef]

111. Kalani, M.Y.; Cheshier, S.H.; Cord, B.J.; Bababeygy, S.R.; Vogel, H.; Weissman, I.L.; Palmer, T.D.; Nusse, R. Wnt-mediated self-renewal of neural stem/progenitor cells. Proc. Natl. Acad. Sci. USA 2008, 105, 16970-16975. [CrossRef]

112. Viti, J.; Gulacsi, A.; Lillien, L. Wnt regulation of progenitor maturation in the cortex depends on Shh or fibroblast growth factor 2. J. Neurosci. 2003, 23, 5919-5927. [CrossRef]

113. Lyu, J.; Joo, C.K. Wnt signaling enhances FGF2-triggered lens fiber cell differentiation. Development 2004, 131, 1813-1824. [CrossRef]

114. Kuwabara, T.; Hsieh, J.; Muotri, A.; Yeo, G.; Warashina, M.; Lie, D.C.; Moore, L.; Nakashima, K.; Asashima, M.; Gage, F.H. Wnt-mediated activation of NeuroD1 and retro-elements during adult neurogenesis. Nat. Neurosci. 2009, 12, 1097-1105. [CrossRef]

115. Munji, R.N.; Choe, Y.; Li, G.; Siegenthaler, J.A.; Pleasure, S.J. Wnt signaling regulates neuronal differentiation of cortical intermediate progenitors. J. Neurosci. 2011, 31, 1676-1687. [CrossRef] [PubMed]

116. Wang, Q.; Charych, E.I.; Pulito, V.L.; Lee, J.B.; Graziane, N.M.; Crozier, R.A.; Revilla-Sanchez, R.; Kelly, M.P.; Dunlop, A.J.; Murdoch, H.; et al. The psychiatric disease risk factors DISC1 and TNIK interact to regulate synapse composition and function. Mol. Psychiatry 2011, 16, 1006-1023. [CrossRef] [PubMed]

117. De Rienzo, G.; Bishop, J.A.; Mao, Y.; Pan, L.; Ma, T.P.; Moens, C.B.; Tsai, L.H.; Sive, H. Disc1 regulates both beta-catenin-mediated and noncanonical Wnt signaling during vertebrate embryogenesis. FASEB J. 2011, 25, 4184-4197. [CrossRef]

118. Lie, D.C.; Colamarino, S.A.; Song, H.J.; Desire, L.; Mira, H.; Consiglio, A.; Lein, E.S.; Jessberger, S.; Lansford, H.; Dearie, A.R.; et al. Wnt signalling regulates adult hippocampal neurogenesis. Nature 2005, 437, 1370-1375. [CrossRef]

119. L’Episcopo, F.; Serapide, M.F.; Tirolo, C.; Testa, N.; Caniglia, S.; Morale, M.C.; Pluchino, S.; Marchetti, B. A Wnt1 regulated Frizzled1 /beta-Catenin signaling pathway as a candidate regulatory circuit controlling mesencephalic dopaminergic neuron-astrocyte crosstalk: Therapeutical relevance for neuron survival and neuroprotection. Mol. Neurodegener. 2011, 6, 49. [CrossRef]

120. Faulkner, R.L.; Jang, M.H.; Liu, X.B.; Duan, X.; Sailor, K.A.; Kim, J.Y.; Ge, S.; Jones, E.G.; Ming, G.L.; Song, H.; et al. Development of hippocampal mossy fiber synaptic outputs by new neurons in the adult brain. Proc. Natl. Acad. Sci. USA 2008, 105, 14157-14162. [CrossRef]

121. Alvarez, A.R.; Godoy, J.A.; Mullendorff, K.; Olivares, G.H.; Bronfman, M.; Inestrosa, N.C. Wnt-3a overcomes beta-amyloid toxicity in rat hippocampal neurons. Exp. Cell Res. 2004, 297, 186-196. [CrossRef] [PubMed]

122. Chong, Z.Z.; Maiese, K. Targeting WNT, protein kinase B, and mitochondrial membrane integrity to foster cellular survival in the nervous system. Histol. Histopathol. 2004, 19, 495-504.

123. Sahores, M.; Gibb, A.; Salinas, P.C. Frizzled-5, a receptor for the synaptic organizer Wnt7a, regulates activity-mediated synaptogenesis. Development 2010, 137, 2215-2225. [CrossRef]

124. Klassen, M.P.; Shen, K. Wnt signaling positions neuromuscular connectivity by inhibiting synapse formation in C. elegans. Cell 2007, 130, 704-716. [CrossRef]

125. Hall, A.C.; Lucas, F.R.; Salinas, P.C. Axonal remodeling and synaptic differentiation in the cerebellum is regulated by WNT-7a signaling. Cell 2000, 100, 525-535. [CrossRef]

126. Krylova, O.; Messenger, M.J.; Salinas, P.C. Dishevelled-1 regulates microtubule stability: A new function mediated by glycogen synthase kinase-3beta. J. Cell Biol. 2000, 151, 83-94. [CrossRef]

127. Lyuksyutova, A.I.; Lu, C.C.; Milanesio, N.; King, L.A.; Guo, N.; Wang, Y.; Nathans, J.; Tessier-Lavigne, M.; Zou, Y. Anteriorposterior guidance of commissural axons by Wnt-frizzled signaling. Science 2003, 302, 1984-1988. [CrossRef] [PubMed]

128. Zechner, D.; Fujita, Y.; Hülsken, J.; Müller, T.; Walther, I.; Taketo, M.M.; Crenshaw, I.I.I.E.B.; Birchmeier, W.; Birchmeier, C. $\beta$-Catenin signals regulate cell growth and the balance between progenitor cell expansion and differentiation in the nervous system. Dev. Biol. 2003, 258, 406-418. [CrossRef]

129. De Ligt, J.; Willemsen, M.H.; van Bon, B.W.; Kleefstra, T.; Yntema, H.G.; Kroes, T.; Vulto-van Silfhout, A.T.; Koolen, D.A.; de Vries, P.; Gilissen, C.; et al. Diagnostic exome sequencing in persons with severe intellectual disability. N. Engl. J. Med. 2012, 367, 1921-1929. [CrossRef] [PubMed]

130. Kuechler, A.; Willemsen, M.H.; Albrecht, B.; Bacino, C.A.; Bartholomew, D.W.; van Bokhoven, H.; van den Boogaard, M.J.; Bramswig, N.; Buttner, C.; Cremer, K.; et al. De novo mutations in beta-catenin (CTNNB1) appear to be a frequent cause of intellectual disability: Expanding the mutational and clinical spectrum. Hum. Genet. 2015, 134, 97-109. [CrossRef]

131. Winczewska-Wiktor, A.; Badura-Stronka, M.; Monies-Nowicka, A.; Nowicki, M.M.; Steinborn, B.; Latos-Bielenska, A.; Monies, D. A de novo CTNNB1 nonsense mutation associated with syndromic atypical hyperekplexia, microcephaly and intellectual disability: A case report. BMC Neurol. 2016, 16, 35. [CrossRef]

132. Kharbanda, M.; Pilz, D.T.; Tomkins, S.; Chandler, K.; Saggar, A.; Fryer, A.; McKay, V.; Louro, P.; Smith, J.C.; Burn, J.; et al. Clinical features associated with CTNNB1 de novo loss of function mutations in ten individuals. Eur. J. Med Genet. 2017, 60, 130-135. [CrossRef]

133. Dubruc, E.; Putoux, A.; Labalme, A.; Rougeot, C.; Sanlaville, D.; Edery, P. A new intellectual disability syndrome caused by CTNNB1 haploinsufficiency. Am. J. Med. Genet. Part A 2014, 164A, 1571-1575. [CrossRef] 
134. Tucci, V.; Kleefstra, T.; Hardy, A.; Heise, I.; Maggi, S.; Willemsen, M.H.; Hilton, H.; Esapa, C.; Simon, M.; Buenavista, M.T.; et al. Dominant beta-catenin mutations cause intellectual disability with recognizable syndromic features. J. Clin. Investig. 2014, 124, 1468-1482. [CrossRef]

135. O’Roak, B.J.; Vives, L.; Girirajan, S.; Karakoc, E.; Krumm, N.; Coe, B.P.; Levy, R.; Ko, A.; Lee, C.; Smith, J.D.; et al. Sporadic autism exomes reveal a highly interconnected protein network of de novo mutations. Nature 2012, 485, 246-250. [CrossRef]

136. Stessman, H.A.; Xiong, B.; Coe, B.P.; Wang, T.; Hoekzema, K.; Fenckova, M.; Kvarnung, M.; Gerdts, J.; Trinh, S.; Cosemans, N.; et al. Targeted sequencing identifies 91 neurodevelopmental-disorder risk genes with autism and developmental-disability biases. Nat. Genet. 2017, 49, 515-526. [CrossRef] [PubMed]

137. O’Roak, B.J.; Vives, L.; Fu, W.; Egertson, J.D.; Stanaway, I.B.; Phelps, I.G.; Carvill, G.; Kumar, A.; Lee, C.; Ankenman, K.; et al. Multiplex Targeted Sequencing Identifies Recurrently Mutated Genes in Autism Spectrum Disorders. Science 2012. [CrossRef] [PubMed]

138. Iakoucheva, L.M.; Muotri, A.R.; Sebat, J. Getting to the Cores of Autism. Cell 2019, 178, 1287-1298. [CrossRef]

139. Krupp, D.R.; Barnard, R.A.; Duffourd, Y.; Evans, S.A.; Mulqueen, R.M.; Bernier, R.; Rivière, J.-B.; Fombonne, E.; O’Roak, B.J. Exonic Mosaic Mutations Contribute Risk for Autism Spectrum Disorder. Am. J. Hum. Genet. 2017, 101, 369-390. [CrossRef]

140. Dong, F.; Jiang, J.; McSweeney, C.; Zou, D.; Liu, L.; Mao, Y. Deletion of CTNNB1 in inhibitory circuitry contributes to autismassociated behavioral defects. Hum. Mol. Genet. 2016, 25, 2738-2751. [CrossRef]

141. Mohn, J.L.; Alexander, J.; Pirone, A.; Palka, C.D.; Lee, S.Y.; Mebane, L.; Haydon, P.G.; Jacob, M.H. Adenomatous polyposis coli protein deletion leads to cognitive and autism-like disabilities. Mol. Psychiatry 2014, 19, 1133-1142. [CrossRef]

142. Lijam, N.; Paylor, R.; McDonald, M.P.; Crawley, J.N.; Deng, C.-X.; Herrup, K.; Stevens, K.E.; Maccaferri, G.; McBain, C.J.; Sussman, D.J.; et al. Social Interaction and Sensorimotor Gating Abnormalities in Mice Lacking Dvl1. Cell 1997, 90, 895-905. [CrossRef]

143. Shin, S.; Santi, A.; Huang, S. Conditional Pten knockout in parvalbumin- or somatostatin-positive neurons sufficiently leads to autism-related behavioral phenotypes. Mol. Brain 2021, 14, 24. [CrossRef]

144. Busch, R.M.; Srivastava, S.; Hogue, O.; Frazier, T.W.; Klaas, P.; Hardan, A.; Martinez-Agosto, J.A.; Sahin, M.; Eng, C. Neurobehavioral phenotype of autism spectrum disorder associated with germline heterozygous mutations in PTEN. Transl. Psychiatry 2019, 9, 253. [CrossRef]

145. Chen, C.-J.; Sgritta, M.; Mays, J.; Zhou, H.; Lucero, R.; Park, J.; Wang, I.C.; Park, J.H.; Kaipparettu, B.A.; Stoica, L.; et al. Therapeutic inhibition of mTORC2 rescues the behavioral and neurophysiological abnormalities associated with Pten-deficiency. Nat. Med. 2019, 25, 1684-1690. [CrossRef] [PubMed]

146. Lugo, J.N.; Smith, G.D.; Arbuckle, E.P.; White, J.; Holley, A.J.; Floruta, C.M.; Ahmed, N.; Gomez, M.C.; Okonkwo, O. Deletion of PTEN produces autism-like behavioral deficits and alterations in synaptic proteins. Front. Mol. Neurosci. 2014, 7. [CrossRef]

147. Kramps, T.; Peter, O.; Brunner, E.; Nellen, D.; Froesch, B.; Chatterjee, S.; Murone, M.; Züllig, S.; Basler, K. Wnt/Wingless Signaling Requires BCL9/Legless-Mediated Recruitment of Pygopus to the Nuclear $\beta$-Catenin-TCF Complex. Cell 2002, 109, 47-60. [CrossRef]

148. Brembeck, F.H.; Schwarz-Romond, T.; Bakkers, J.; Wilhelm, S.; Hammerschmidt, M.; Birchmeier, W. Essential role of BCL9-2 in the switch between $\beta$-catenin's adhesive and transcriptional functions. Genes Dev. 2004, 18, 2225-2230. [CrossRef]

149. Mieszczanek, J.; de la Roche, M.; Bienz, M. A role of Pygopus as an anti-repressor in facilitating Wnt-dependent transcription. Proc. Natl. Acad. Sci. USA 2008, 105, 19324-19329. [CrossRef]

150. Brack, A.S.; Murphy-Seiler, F.; Hanifi, J.; Deka, J.; Eyckerman, S.; Keller, C.; Aguet, M.; Rando, T.A. BCL9 is an essential component of canonical Wnt signaling that mediates the differentiation of myogenic progenitors during muscle regeneration. Dev. Biol. 2009, 335, 93-105. [CrossRef] [PubMed]

151. Xu, C.; Aragam, N.; Li, X.; Villla, E.C.; Wang, L.; Briones, D.; Petty, L.; Posada, Y.; Arana, T.B.; Cruz, G.; et al. BCL9 and C9orf5 Are Associated with Negative Symptoms in Schizophrenia: Meta-Analysis of Two Genome-Wide Association Studies. PLoS ONE 2013, 8, e51674. [CrossRef]

152. Kimura, H.; Tanaka, S.; Kushima, I.; Koide, T.; Banno, M.; Kikuchi, T.; Nakamura, Y.; Shiino, T.; Yoshimi, A.; Oya-Ito, T.; et al. Association study of BCL9 gene polymorphism rs583583 with schizophrenia and negative symptoms in Japanese population. Sci. Rep. 2015, 5, 15705. [CrossRef]

153. Luo, X.; Huang, L.; Han, L.; Luo, Z.; Hu, F.; Tieu, R.; Gan, L. Systematic Prioritization and Integrative Analysis of Copy Number Variations in Schizophrenia Reveal Key Schizophrenia Susceptibility Genes. Schizophr. Bull. 2014, 40, 1285-1299. [CrossRef]

154. Takada, K.; Zhu, D.; Bird, G.H.; Sukhdeo, K.; Zhao, J.-J.; Mani, M.; Lemieux, M.; Carrasco, D.E.; Ryan, J.; Horst, D.; et al. Targeted Disruption of the BCL9/ $\beta$-Catenin Complex Inhibits Oncogenic Wnt Signaling. Sci. Transl. Med. 2012, 4, 148ra117. [CrossRef]

155. Moor, A.E.; Anderle, P.; Cantù, C.; Rodriguez, P.; Wiedemann, N.; Baruthio, F.; Deka, J.; André, S.; Valenta, T.; Moor, M.B.; et al. BCL9/9L- $\beta$-catenin Signaling is Associated With Poor Outcome in Colorectal Cancer. EBioMedicine 2015, 2, 1932-1943. [CrossRef]

156. Beaulieu, J.-F. Tuning WNT- $\beta$-catenin signaling via BCL9 proteins for targeting colorectal cancer cells. EBioMedicine 2015, 2 , 1846-1847. [CrossRef]

157. Miyaoka, T.; Seno, H.; Ishino, H. Increased expression of Wnt-1 in schizophrenic brains. Schizophr. Res. 1999, 38, 1-6. [CrossRef]

158. Proitsi, P.; Li, T.; Hamilton, G.; Di Forti, M.; Collier, D.; Killick, R.; Chen, R.; Sham, P.; Murray, R.; Powell, J.; et al. Positional pathway screen of wnt signaling genes in schizophrenia: Association with DKK4. Biol. Psychiatry 2008, 63, 13-16. [CrossRef]

159. Yang, J.; Si, T.; Ling, Y.; Ruan, Y.; Han, Y.; Wang, X.; Zhang, H.; Kong, Q.; Li, X.; Liu, C.; et al. Association study of the human FZD3 locus with schizophrenia. Biol. Psychiatry 2003, 54, 1298-1301. [CrossRef] 
160. Ide, M.; Muratake, T.; Yamada, K.; Iwayama-Shigeno, Y.; Iwamoto, K.; Takao, H.; Toyota, T.; Kaneko, N.; Minabe, Y.; Nakamura, K.; et al. Genetic and expression analyses of FZD3 in schizophrenia. Biol. Psychiatry 2004, 56, 462-465. [CrossRef] [PubMed]

161. Zhang, Y.; Yu, X.; Yuan, Y.; Ling, Y.; Ruan, Y.; Si, T.; Lu, T.; Wu, S.; Gong, X.; Zhu, Z.; et al. Positive association of the human frizzled 3 (FZD3) gene haplotype with schizophrenia in Chinese Han population. Am. J. Med. Genet. B Neuropsychiatr. Genet. 2004, 129, 16-19. [CrossRef]

162. Lachman, H.M.; Pedrosa, E.; Petruolo, O.A.; Cockerham, M.; Papolos, A.; Novak, T.; Papolos, D.F.; Stopkova, P. Increase in GSK3beta gene copy number variation in bipolar disorder. Am. J. Med. Genet. B Neuropsychiatr. Genet. 2007, 144, $259-265$. [CrossRef]

163. Martin, P.M.; Yang, X.; Robin, N.; Lam, E.; Rabinowitz, J.S.; Erdman, C.A.; Quinn, J.; Weiss, L.A.; Hamilton, S.P.; Kwok, P.Y.; et al. A rare WNT1 missense variant overrepresented in ASD leads to increased Wnt signal pathway activation. Transl. Psychiatry 2013, 3, e301. [CrossRef]

164. Millar, J.K.; Wilson-Annan, J.C.; Anderson, S.; Christie, S.; Taylor, M.S.; Semple, C.A.; Devon, R.S.; Clair, D.M.; Muir, W.J.; Blackwood, D.H.; et al. Disruption of two novel genes by a translocation co-segregating with schizophrenia. Hum. Mol. Genet. 2000, 9, 1415-1423. [CrossRef]

165. Kim, H.J.; Park, H.J.; Jung, K.H.; Ban, J.Y.; Ra, J.; Kim, J.W.; Park, J.K.; Choe, B.K.; Yim, S.V.; Kwon, Y.K.; et al. Association study of polymorphisms between DISC1 and schizophrenia in a Korean population. Neurosci. Lett. 2007, 26, 81-96. [CrossRef]

166. Tomppo, L.; Hennah, W.; Lahermo, P.; Loukola, A.; Tuulio-Henriksson, A.; Suvisaari, J.; Partonen, T.; Ekelund, J.; Lonnqvist, J.; Peltonen, L. Association between genes of Disrupted in schizophrenia 1 (DISC1) interactors and schizophrenia supports the role of the DISC1 pathway in the etiology of major mental illnesses. Biol. Psychiatry 2009, 65, 1055-1062. [CrossRef]

167. Schosser, A.; Gaysina, D.; Cohen-Woods, S.; Chow, P.C.; Martucci, L.; Craddock, N.; Farmer, A.; Korszun, A.; Gunasinghe, C.; Gray, J.; et al. Association of DISC1 and TSNAX genes and affective disorders in the depression case-control (DeCC) and bipolar affective case-control (BACCS) studies. Mol. Psychiatry 2009. [CrossRef]

168. Hennah, W.; Thomson, P.; McQuillin, A.; Bass, N.; Loukola, A.; Anjorin, A.; Blackwood, D.; Curtis, D.; Deary, I.J.; Harris, S.E.; et al. DISC1 association, heterogeneity and interplay in schizophrenia and bipolar disorder. Mol. Psychiatry 2009, 14, 865-873. [CrossRef]

169. Kilpinen, H.; Ylisaukko-Oja, T.; Hennah, W.; Palo, O.M.; Varilo, T.; Vanhala, R.; Nieminen-von Wendt, T.; von Wendt, L.; Paunio, T.; Peltonen, L. Association of DISC1 with autism and Asperger syndrome. Mol. Psychiatry 2007, 13, 187-196. [CrossRef]

170. Mao, Y.; Ge, X.; Frank, C.L.; Madison, J.M.; Koehler, A.N.; Doud, M.K.; Tassa, C.; Berry, E.M.; Soda, T.; Singh, K.K.; et al. Disrupted in schizophrenia 1 regulates neuronal progenitor proliferation via modulation of GSK3beta/beta-catenin signaling. Cell 2009, 136, 1017-1031. [CrossRef]

171. Tansey, K.E.; Rees, E.; Linden, D.E.; Ripke, S.; Chambert, K.D.; Moran, J.L.; McCarroll, S.A.; Holmans, P.; Kirov, G.; Walters, J.; et al. Common alleles contribute to schizophrenia in CNV carriers. Mol. Psychiatry 2016, 21, 1085-1089. [CrossRef]

172. Benítez-Burraco, A.; Barcos-Martínez, M.; Espejo-Portero, I.; Fernández-Urquiza, M.; Torres-Ruiz, R.; Rodríguez-Perales, S.; Jiménez-Romero, M.S. Narrowing the Genetic Causes of Language Dysfunction in the 1q21.1 Microduplication Syndrome. Front. Pediatrics 2018, 6. [CrossRef]

173. Xavier, J.; Zhou, B.; Bilan, F.; Zhang, X.; Gilbert-Dussardier, B.; Viaux-Savelon, S.; Pattni, R.; Ho, S.S.; Cohen, D.; Levinson, D.F.; et al. 1q21.1 microduplication: Large verbal-nonverbal performance discrepancy and ddPCR assays of HYDIN/HYDIN2 copy number. NPJ Genom. Med. 2018, 3, 24. [CrossRef]

174. Polyak, A.; Rosenfeld, J.A.; Girirajan, S. An assessment of sex bias in neurodevelopmental disorders. Genome Med. 2015, 7, 94. [CrossRef] [PubMed]

175. Nestler, E.J.; Hyman, S.E. Animal models of neuropsychiatric disorders. Nat. Neurosci. 2010, 13, 1161-1169. [CrossRef] [PubMed]

176. Ellegood, J.; Crawley, J.N. Behavioral and Neuroanatomical Phenotypes in Mouse Models of Autism. Neurotherapeutics 2015, 12, 521-533. [CrossRef]

177. Pedrosa, E.; Sandler, V.; Shah, A.; Carroll, R.; Chang, C.; Rockowitz, S.; Guo, X.; Zheng, D.; Lachman, H.M. Development of Patient-Specific Neurons in Schizophrenia Using Induced Pluripotent Stem Cells. J. Neurogenet. 2011, 25, 88-103. [CrossRef]

178. Giovanoli, S.; Engler, H.; Engler, A.; Richetto, J.; Voget, M.; Willi, R.; Winter, C.; Riva, M.A.; Mortensen, P.B.; Feldon, J.; et al. Stress in Puberty Unmasks Latent Neuropathological Consequences of Prenatal Immune Activation in Mice. Science 2013, 339, 1095-1099. [CrossRef] [PubMed]

179. Gandal, M.J.; Haney, J.R.; Parikshak, N.N.; Leppa, V.; Ramaswami, G.; Hartl, C.; Schork, A.J.; Appadurai, V.; Buil, A.; Werge, T.M.; et al. Shared molecular neuropathology across major psychiatric disorders parallels polygenic overlap. Science 2018, 359, 693-697. [CrossRef]

180. Radtke, F.A.; Chapman, G.; Hall, J.; Syed, Y.A. Modulating Neuroinflammation to Treat Neuropsychiatric Disorders. Biomed Res. Int. 2017, 2017, 5071786. [CrossRef]

181. Ripke, S.; Neale, B.M.; Corvin, A.; Walters, J.T.R.; Farh, K.-H.; Holmans, P.A.; Lee, P.; Bulik-Sullivan, B.; Collier, D.A.; Huang, H.; et al. Biological insights from 108 schizophrenia-associated genetic loci. Nature 2014, 511, 421-427. [CrossRef]

182. Pape, K.; Tamouza, R.; Leboyer, M.; Zipp, F. Immunoneuropsychiatry-Novel perspectives on brain disorders. Nat. Rev. Neurol. 2019, 15, 317-328. [CrossRef] 